\title{
Effect of Platooning on Fuel Consumption of Class 8 Vehicles Over a Range of Speeds, Following Distances, and Mass
}

\author{
Michael P. Lammert and Adam Duran \\ National Renewable Energy Laboratory \\ Jeremy Diez and Kevin Burton \\ Intertek
}

Alex Nicholson

Link Engineering Company

\begin{abstract}
This research project evaluates fuel consumption results of two Class 8 tractor-trailer combinations platooned together compared to their standalone fuel consumption. A series of ten modified SAE Type II J1321 fuel consumption track tests were performed to document fuel consumption of two platooned vehicles and a control vehicle at varying steady-state speeds, following distances, and gross vehicle weights (GVWs). The steady-state speeds ranged from $55 \mathrm{mph}$ to $70 \mathrm{mph}$, the following distances ranged from a 20 -ft following distance to a 75 - $\mathrm{ft}$ following distance, and the GVWs were $65 \mathrm{~K}$ lbs and $80 \mathrm{~K}$ Ibs. All tractors involved had U.S. Environmental Protection Agency (EPA) SmartWay-compliant aerodynamics packages installed, and the trailers were equipped with side skirts. Effects of vehicle speed, following distance, and GVW on fuel consumption were observed and analyzed. The platooning demonstration system used in this study consisted of radar systems, Dedicated Short-Range Communication (DSRC) vehicle-to-vehicle (V2V) communications, vehicle braking and torque control interface, cameras and driver displays. The lead tractor consistently demonstrated an improvement in average fuel consumption reduction as following distance decreased, with results showing $2.7 \%$ to $5.3 \%$ fuel savings at a GVW of $65 \mathrm{k}$. The trailing vehicle achieved fuel consumption savings ranging from $2.8 \%$ to $9.7 \%$; tests during which the engine cooling fan did not operate achieved savings of $8.4 \%$ to $9.7 \%$. "Team" fuel savings, considering the platooned vehicles as one, ranged from $3.7 \%$ to $6.4 \%$, with the best combined result being for $55 \mathrm{mph}, 30$-ft following distance, and $65 k$ GVW.
\end{abstract}

CITATION: Lammert, M., Duran, A., Diez, J., Burton, K. et al., "Effect of Platooning on Fuel Consumption of Class 8 Vehicles Over a Range of Speeds, Following Distances, and Mass," SAE Int. J. Commer. Veh. 7(2):2014, doi:10.4271/2014-01-2438.

\section{INTRODUCTION}

Vehicle automation is a promising petroleum reduction technology, and platooning systems for heavy-duty vehicles are likely to be a first step towards acceptance of vehicle automation. These systems may employ existing technologies such as radar or laser range finders, global positioning system (GPS), dedicated vehicle-to-vehicle communications (V2V), and braking and engine torque authority to enable vehicles to follow safely in close proximity with the goal of reducing fuel consumption, traffic congestion, and possibly collisions.
Early studies have consistently suggested significant fuel savings from the reduced aerodynamic drag; however, because platooning systems are still emerging technologies that are not yet commercially available, questions remain about how effective they will be at reducing fuel consumption in the real world and under what conditions they will perform best.

As part of the California Partners for Advanced Transportation Technology (PATH) program, Browand et al. found that platooning vehicles were able to achieve $8 \%-11 \%$ in fuel consumption savings from 3- to 10-meter following distance. Tests were conducted on an unused runway in two directions with a usable 220-350 meter overlap to collect data. Two 
identical 2001 Freightliner Century Class trucks powered by Cummins N14 Celect engines were used in the testing with empty or lightly loaded trailers. The fuel rate was derived from on-board vehicle bus communication signals versus weighing tanks, and test speeds of 50-55 mph were employed. Spacing of 10 meters found $10 \%$ and $6 \%$ fuel consumption savings, respectively, for the trailing and lead truck. In the spacing range of 3-10 meters, fuel consumption was reduced in the range $10 \%-12 \%$ for the trailing truck and $5 \%-10 \%$ for the lead truck. Vehicle mass was not specified, but the test trailers were empty. [1]

Alam et al. found a maximum fuel reduction of $4.7 \%-7.7 \%$ depending on the following distance at a set speed of $70 \mathrm{~km} / \mathrm{h}$ (44 mph) with two identical European cab-over trucks at 40,000 $\mathrm{kg}(88 \mathrm{~K}$ lbs GVW) [2].

Tsugawa et al. showed through modeling and track testing that a three-truck platoon at $80 \mathrm{~km} / \mathrm{h}$ (50 mph) and a 10-meter following distance could improve fuel consumption by an average of $14 \%$ with the lead truck experiencing a $7.5 \%$ reduction and the tail truck experiencing a $16 \%$ reduction. European style cab-over tractors were used, and vehicle mass was not specified. []]

The New Energy and Industrial Technology Development Organization (NEDO) in Japan showed with track testing that a platoon of four cab-over straight trucks maintaining a 4-meter following distance and $80 \mathrm{~km} / \mathrm{h}$ (50 mph) speeds attained a $15 \%$ average improvement. Vehicle mass was not specified. [4]

This research project, funded by the Department of Energy (DOE), evaluated the fuel consumption reduction of a pair of platooned Class 8 tractor-trailers on a track over a range of highway truck speeds, following distances, and weights that would represent driving on public road conditions under test track conditions. The project was managed by the National Renewable Energy Laboratory (NREL), and the tests were performed by Intertek Testing Services NA and LINK Engineering. Testing took place at the Continental Tire Proving Grounds [5] in Uvalde, Texas, which is an 8.5-mile (13.7-km)) asphalt oval with several small grade changes rather than a zero grade environment. As such, the constant-speed tests operated under cruise control had an average speed standard deviation of $\pm 0.6 \mathrm{mph}$ and a maximum deviation of $1.0 \mathrm{mph}$ as the heavy tractors responded to the small grade changes. The fuel consumption savings were recorded through methods prescribed in SAE J1321 Fuel Consumption Test Procedure [6]. Effects on engine cooling to the trailing vehicle from platooning were recorded with data logging devices through the use of J1939 controller area network (CAN) bus messages [7].

\section{BACKGROUND AND METHODS}

\section{Test Track Selection}

The Continental Tire Uvalde Proving Grounds track is a three-lane wide, 8.5 -mile $(13.7 \mathrm{~km})$ oval with one-mile radius turns and a 1.1-mile straightaway between the turns. The oval track is shown in a satellite view in Figure 1. The track is not perfectly level, but rather has several small elevation changes of approximately $15 \mathrm{ft}$, resulting in gentle grade changes throughout the lap.

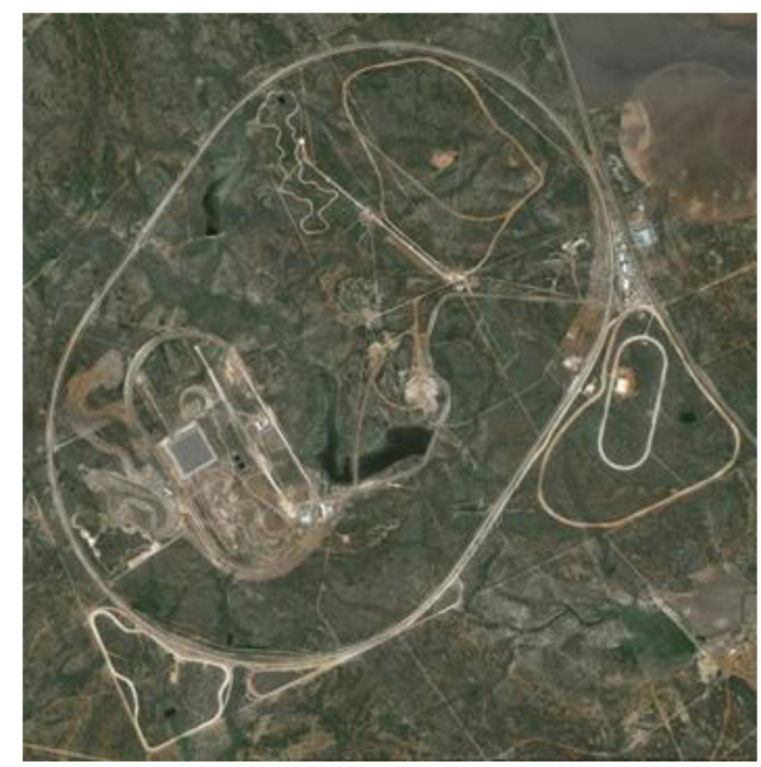

Figure 1. 8.5-mile oval at Continental Tire Uvalde Proving Grounds (๑) Google Earth)

\section{Vehicle Selection and Details}

Several previous studies tested platooning on older tractors, which paid less attention to base aerodynamics than many tractors popular in the United States today or cab-over designs popular outside the United States, which may respond to platooning differently $[1, \underline{2}, \underline{3}, \underline{4}]$. In this study, modern "aero" model tractors with EPA's SmartWay-compliant [] design packages and trailer side skirts were tested. The authors feel that this should be more representative of fleets that would adopt platooning technology in the United States if it becomes available, as many fleets are currently making aerodynamic packages standard across their fleet. EPA Phase 2 greenhouse gas emissions and fuel efficiency standards in preliminary rulemaking likely will make improved aerodynamics standard across the new Class 8 truck population. Table 1 lists the test tractor and trailer specifications. Figures $2, \underline{3}$, and $\underline{4}$ show the lead, trailing, and control test tractor-trailer combinations, respectively. 
Table 1. Test tractor and trailer specifications

\begin{tabular}{|c|c|c|c|}
\hline Van Specification & $\begin{array}{l}\text { Lead Tractor- } \\
\text { Trailer }\end{array}$ & $\begin{array}{l}\text { Trailing } \\
\text { Tractor-Trailer }\end{array}$ & $\begin{array}{l}\text { Control } \\
\text { Tractor-Trailer }\end{array}$ \\
\hline Manufacturer & Peterbilt & Peterbilt & Peterbilt \\
\hline Model & 386 & 386 & 579 \\
\hline Model year & 2011 & 2011 & 2013 \\
\hline $\begin{array}{l}\text { Vehicle Mileage at } \\
\text { Test Start }\end{array}$ & 325,367 & 360,334 & 43,618 \\
\hline Engine manufacturer & Cummins & Cummins & PACCAR \\
\hline Engine model & ISX-15 450 & ISX-15 450 & $M X-13475$ \\
\hline Engine model year & 2010 & 2010 & 2010 \\
\hline Emissions equipment & DOC/DPF/SCR & DOC/DPF/SCR & DOC/DPF/SCR \\
\hline Transmission & $\begin{array}{l}\text { Eaton Fuller } \\
10 \text {-speed }\end{array}$ & $\begin{array}{l}\text { Eaton Fuller } \\
10 \text {-speed }\end{array}$ & $\begin{array}{l}\text { Eaton Fuller } \\
10 \text {-speed }\end{array}$ \\
\hline $\begin{array}{l}\text { Retarder/regenerative } \\
\text { braking }\end{array}$ & Engine Brake & Engine Brake & Engine Brake \\
\hline Tires & $\begin{array}{l}\text { Michelin } \\
\text { XDA Energy }\end{array}$ & $\begin{array}{l}\text { Michelin } \\
\text { XDA Energy }\end{array}$ & $\begin{array}{l}\text { Goodyear Fuel } \\
\text { MAX }\end{array}$ \\
\hline $\begin{array}{l}\text { Cab Fairing to nose } \\
\text { of trailer (visible } \\
\text { space between } \\
\text { tractor and trailer) }\end{array}$ & $50 "$ & $50 "$ & $41^{\prime \prime}$ \\
\hline Trailer Configuration & $\begin{array}{l}\text { 53-ft Van } \\
\text { Trailer with } \\
\text { angled side } \\
\text { skirts }\end{array}$ & $\begin{array}{l}\text { 53-ft Van } \\
\text { Trailer with } \\
\text { angled side } \\
\text { skirts }\end{array}$ & $\begin{array}{l}\text { 53-ft Van } \\
\text { Trailer with } \\
\text { angled side } \\
\text { skirts }\end{array}$ \\
\hline Trailer Manufacturer & Great Dane & Stoughton & Wabash \\
\hline Trailer Model & 74111 SSLAK & $\begin{array}{l}\text { 2GPVW-53ST- } \\
\text { S-L-AR }\end{array}$ & TRA/ VAN \\
\hline Trailer Height & $13^{\prime} 6^{\prime \prime}$ & $13^{\prime} 6^{\prime \prime}$ & $13^{\prime} 6^{\prime \prime}$ \\
\hline Trailer Width & $102 "$ & $102 "$ & $102 "$ \\
\hline King Pin Set Back & $36 "$ & $36 "$ & $36 "$ \\
\hline Trailer Side Skirt & $\begin{array}{l}\text { Freight Wing } \\
\text { AeroFlex }\end{array}$ & $\begin{array}{l}\text { Freight Wing } \\
\text { AeroFlex }\end{array}$ & $\begin{array}{l}\text { DuraPlate } \\
\text { AeroSkirt }\end{array}$ \\
\hline $\begin{array}{l}\text { Distance from rear of } \\
\text { trailer side skirt to } \\
\text { front of trailer wheels }\end{array}$ & $6.5^{\prime \prime}$ & $8.5^{\prime \prime}$ & $9.5^{\prime \prime}$ \\
\hline
\end{tabular}

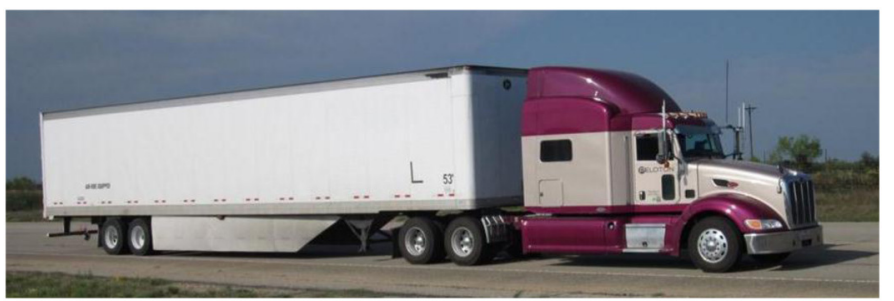

Figure 2. Lead platoon tractor and trailer Photo by Alex Nicholson, Link Engineering Company

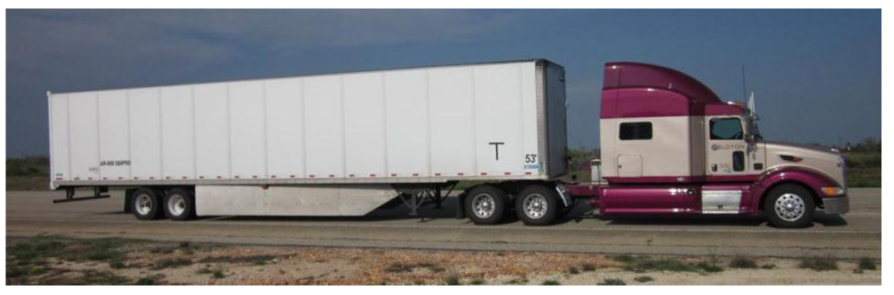

Figure 3. Trailing platoon tractor and trailer; Photo by Alex Nicholson, Link Engineering Company

The platooning demonstration system used is from Peloton Technology, Inc. [9], and includes radar systems, Dedicated Short-Range Communication (DSRC) [10] vehicle-to-vehicle communications, vehicle braking and torque control interface, cameras and driver displays. Table 2 lists the specifications of the platooning demonstration system tested. The system controls the throttle and braking on the rear truck using a combination of inputs including, but not limited to: radarmeasured distance, GPS locations and speeds of both vehicles, lead vehicle wheel-based speed, torque request and braking application. The system does not control lateral position so the trailing truck driver is still responsible for steering, which is a possible source of variation in the tests.

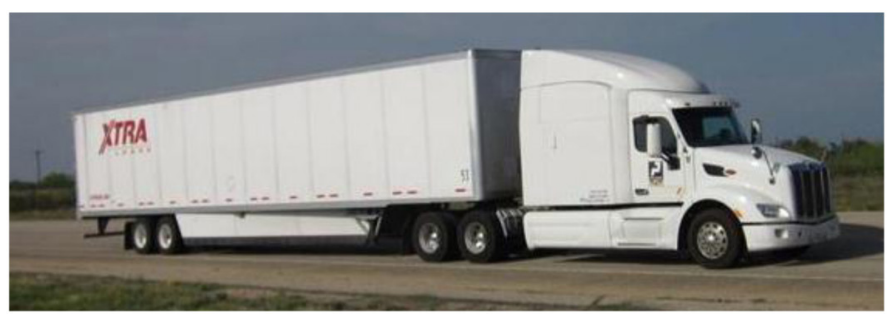

Figure 4. Control tractor and trailer; Photo by Alex Nicholson, Link Engineering Company

Table 2. Demonstration platooning system specifications

\begin{tabular}{|l|l|}
\hline Category & Demonstration Platooning System Description \\
\hline Manufacturer/integrator & Peloton Technology Inc. \\
\hline \multirow{5}{*}{ Radar } & $\begin{array}{l}\text { Delphi Electronic Scanning Radar: } \\
\text { Dual beams } \\
\text { Short range }+/-45 \text { degree beam, 60m range } \\
\text { Long range }+/-10 \text { degree beam 175m range } \\
20 \mathrm{~Hz} \text { update rate } \\
\text { Mounted in front bumper }\end{array}$ \\
\hline Dedicated Short Range & $\begin{array}{l}\text { Denso DSRC Radio WSU 1.5 } \\
\text { Dual antennas in diversity mode } \\
\text { Omni-directional antennae mounted on mirrors } \\
\text { Single } 10 \text { MHz channel } \\
\text { Single-board computer and 5.9 GHz DSRC radio } \\
\text { Supports IEEE } 802.11 \mathrm{p}, \mathrm{P} 1609.3, \mathrm{P} 1609.4, \mathrm{P} 1609.2\end{array}$ \\
\hline \multirow{5}{*}{ Vehicle communications } & $\begin{array}{l}\text { CAN/J1939 interface through interface card in } \\
\text { embedded PC } \\
\text { Private Controller Area Network (CAN) for sensors } \\
\text { J1939 for vehicle bus and actuation }\end{array}$ \\
\hline ABS/Stability control & $\begin{array}{l}\text { Meritor Wabco Brakes } \\
\text { ESC with J1939 brake actuation capability }\end{array}$ \\
\hline
\end{tabular}

\section{Variable Speed Track Testing}

Because some of the nation's highway traffic flow may not enable constant-speed driving for extended durations, a variable speed test was desired. The system used for this testing disengages the platoon formation if a gear shift, transmission neutral, or brake pedal activation is detected. This necessitated a speed trace that the vehicles could accomplish while staying in top gear and using only engine braking to vary the speed. The "Cruise Mode" section of the California Air Resources Board (CARB) Heavy Heavy-Duty Diesel Truck (HHDDT) schedule [11] was used as a starting point, but the speed range was too low for top gear for a standard line haul tractor; therefore, $10 \mathrm{mph}$ was added to all speed points of the HHDDT to bring the trace into the range of highway driving accomplished in top gear for these tractors. This modified HHDDT schedule was repeated roughly 2.5 times to approach 56 miles, intentionally short of the test distance of 59.5 miles. The variable-speed distance was set shorter than the normal test distance both to allow for error in meeting the trace and to allow the vehicles to enter and exit the test under $60 \mathrm{mph}$ in the cruise control condition using normal test procedures. A heads-up driver's aid that displayed the desired speed for the next 30 seconds as well as current GPS speed, very similar to 
driver's aids used in chassis dynamometer testing, was developed to enable the variable speed modified HHDDT testing program. Figure 5 shows a speed trace of the variablespeed program. Drivers were instructed to meet the trace as close as possible, but it was understood that the harder accelerations and decelerations would probably not be matched due to the limitations placed on each driver to remain in the same gear for the entire trace. Additionally, the grade changes of the track meant some accelerations/decelerations occurred on an up or down grade, which either mitigated or exacerbated the difficulty of meeting the trace. Because the trace was time based and started at the same point on the track, all vehicles experienced the same relative duty cycle at each location on the track.

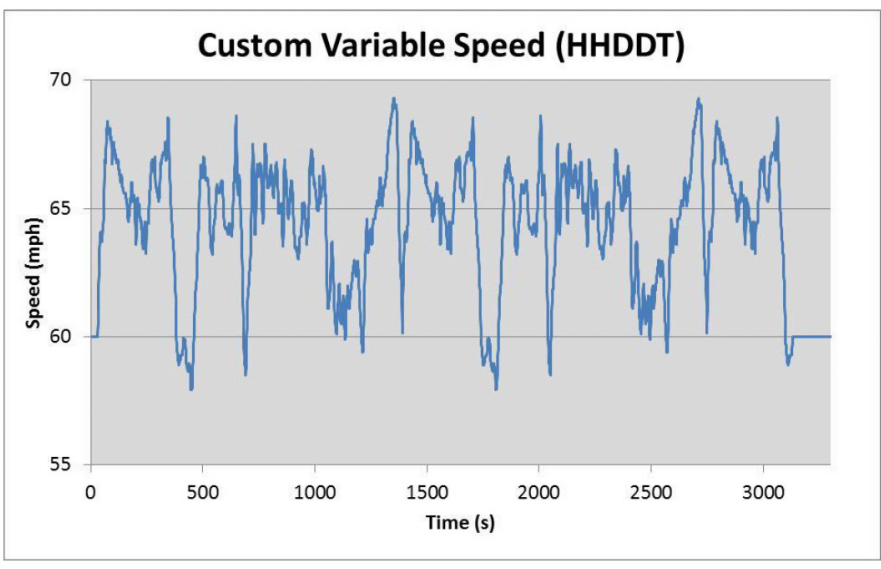

Figure 5. Custom variable-speed test trace based on the HHDDT

\section{Track Testing Procedures}

Track testing methods recommended in SAE J1321 Fuel Consumption Test Procedure - Type II (1986) [] ] were used with some adaptations for platoon testing. The first modification to the procedure was to have two test vehicles compared independently to the control vehicle during baseline and test condition runs. Thus, two test-to-control (T/C) ratios were calculated for each test. The second modification was to utilize a solenoid valve to switch between vehicle fuel tanks for warm up and test tanks for test runs. As such, "run time" is the total elapsed time from energizing the fuel solenoid valve to de-energizing it (simultaneously triggering the J1939 data acquisition system). This was necessary to allow the test vehicles time to attain platoon formation prior to test start and to end platoon formation after test stop. Also, due to the nature of the dynamic interaction between the two test vehicles on test runs, additional variability outside the prescribed $2 \%$ was accepted on three tests. During the initial baseline test at 65 mph with 65,000 GVW and during the $70 \mathrm{ft}$. and $55 \mathrm{ft}$. following distance, the climate control and cab fan settings were kept constant with the air-conditioning clutch engaged and vent mode with a fan setting of " 3 " selected. For each baseline set and test set for the remainder of testing, the air-conditioning clutch was turned off while in vent mode and the fan speed remained at 3 to minimize variability between the control, lead, and trailing trucks. This adjustment was made to eliminate possible variability from the air-conditioning compressor and was made possible by running tests outside the heat of the day. The test runs and respective baseline runs were always conducted using the same settings and as such all ratios were valid.

A full warm-up procedure was conducted at the start of each test day or after the vehicles had been parked for more than 30 minutes. The full warm-up procedure consisted of the following:

- The vehicles were driven for at least seven laps at the speed of the test segment that followed $(55,65,70 \mathrm{mph}$, etc.).

- Fuel was drawn from the vehicle main tank (i.e., not the measured test tank) during the Full Warm-up Procedure.

- The vehicles were platooned together by the end of the warm-up period, allowing the test segment to start immediately upon reaching completion of the warm-up phase.

- Any set points such as cruise control, other speed locking settings, and/or platooning distance settings were set during the Full Warm-up Procedure.

A Partial Warm-up Procedure was conducted if the vehicles were parked for less than 30 minutes, which typically occurred at the end of a test segment. The Partial Warm-up Procedure consisted of the following:

- The vehicles were driven for 16.5 miles at the speed of the test segment to follow $(55,65,70 \mathrm{mph}$, etc.).

- $\quad$ Fuel was drawn from the vehicle main tank (i.e., not the measured test tank) during the Partial Warm-up Procedure.

- The vehicles were platooned together by the end of the warm-up period, allowing the test segment to start immediately upon reaching completion of the Partial Warm-up procedure.

- $\quad$ Any set points such as cruise control, other speed locking settings, and/or platooning distance settings were set during the partial warm-up procedure.

A test run procedure was initiated without pause after the appropriate warm-up procedure was completed. The test run procedure consisted of:

- Three valid test runs are required for each series in the $65 \mathrm{mph}, 65 \mathrm{k}$ GVW condition. Only two test runs per series for other conditions were performed due to budget considerations.

- By the end of the warm-up procedure/beginning of the test run procedure, all three vehicles were at the test speed and the spacing/distance with the cruise control and/or platooning system settings were engaged. 
- As each vehicle crossed the 8.0-mile marker, the driver of each respective vehicle switched from drawing fuel from the vehicle main tank to the measured test tank. The tank switch solenoid also initiated logging by the data loggers. The data loggers were Isaac Instruments DRU-908 devices with $5 \mathrm{~Hz}$ GPS antennas and SAE J1939 CAN bus connections.

- For the variable speed tests, the driver's aid trace was started as each vehicle crossed the 8.5-mile marker after having switched to the measured test tank. On platooning runs, only the lead platoon vehicle and control vehicle initiated the driver's aid.

- The test run consisted of seven laps (59.5 miles total). If conducting a baseline (non-platooning) run, each vehicle had significant spacing (3-5 min). If conducting a test (platooning) run, the control vehicle had significant spacing (3-5 $\mathrm{min}$ ) behind the platooning pair.

- $\quad$ As each vehicle crossed the 8.0-mile marker after the seven test laps were completed, the driver of each respective vehicle switched from drawing fuel from the measured test tank to the vehicle main tank.

- $\quad$ Each vehicle then exited the track and parked in the staging area.

- $\quad$ The measured test tanks were quickly removed and replaced with a replacement measured test tank that had already been fueled and weighed.

- The vehicles were sent back out as quickly as possible to minimize cooling.

- $\quad$ Upon re-entering the track, the vehicles conducted the partial warm-up procedure (unless the transition time was longer than 30 minutes) and then initiated the next test run.

The measurement was defined as the T/C ratio, the ratio of the fuel used by test vehicle to that used by the control vehicle:

$\mathrm{T} / \mathrm{C}$ ratio $=$ fuel used by test vehicle/fuel used by control vehicle In this testing, there were two $\mathrm{T} / \mathrm{C}$ ratios considered for validity checking: one for the lead platooning vehicle and one for the trailing platooning vehicle.

$$
\begin{aligned}
& \text { Lead Vehicle } \mathrm{T} / \mathrm{C} \text { ratio }=\mathrm{T}_{\mathrm{L}} / \mathrm{C} \\
& \text { Trailing Vehicle } \mathrm{T} / \mathrm{C} \text { ratio }=\mathrm{T}_{\mathrm{T}} / \mathrm{C}
\end{aligned}
$$

If the desired number of consecutive runs did not comply with the $2.5 \%$ band, additional runs were completed until the desired number of consecutive runs fell within a $2.5 \%$ band.

Validity checks were completed for each of the test segments: the recorded fuel measurement ratios of three or two runs (per the test plan) were required to be within a $2.5 \%$ band of each other. Values above $2.5 \%$ were not considered valid. All baseline sets were within $1 \%$ variation. However, due to the nature of the platooning test and the need for air conditioning use due to ambient conditions during early testing, three test sets results were higher than the SAE J1321-prescribed $2 \%$ band [ $\underline{5}$ ] but were still accepted; no results higher than $2.5 \%$ were accepted on steady-state test sets. The exception was the variable speed test set, where the previously discussed difficulty in meeting the trace led to a $3.8 \%$ variation on the test runs that were accepted.

An additional $\mathrm{T} / \mathrm{C}$ ratio was calculated during post processing but was not considered during the validity check process.

"Team" fuel savings were calculated in an effort to consider the total fuel savings of a pair of platooned vehicles, without introducing any bias via an averaging method. Team fuel savings were determined by summing both the leading and trailing vehicle fuel consumption and using that value to calculate a new $\mathrm{T} / \mathrm{C}$ ratio measurement.

$$
\text { Team } \mathrm{T} / \mathrm{C} \text { ratio }=\left(\mathrm{T}_{\mathrm{L}}+\mathrm{T}_{\mathrm{T}}\right) / \mathrm{C}
$$

\section{Ambient Conditions Measurement}

Ambient temperature, relative humidity, average wind speed, peak wind speed, wind direction, and barometric pressure measurements were provided by a weather station located at the test track, which recorded the information once a minute. Testing took place over 3 weeks and over much of the day and night; as such ambient conditions during testing ranged as well. Average wind speeds over the course of a test ranged from $2 \mathrm{mph}$ to $11.7 \mathrm{mph}$. Average temperatures ranged from $13^{\circ}$ to $32^{\circ} \mathrm{C}$. Relative humidity ranged from $17 \%$ to $88 \%$.

\section{Fuel Consumption Measurement}

The fuel consumption measurement in this project relied on a gravimetric approach. The engine fuel supply and return lines were connected to a fuel container placed on the frame rails behind the cab. The driver controlled a switch between the test tanks and main vehicle tanks. The difference between the beginning and the end of test mass measurement indicated the mass of fuel consumed during the test. Each day, the scale calibration was verified with a known calibration weight. A Sartorius ISI-10 scale with $0.002 \mathrm{~kg}$ readability and NIST traceable calibration on site at the Continental Tire Proving Grounds was used for this test. Engine fuel rate from the SAE J1939 CAN bus was also recorded as an investigative method, not to back up the gravimetric fuel measurement but rather to be evaluated alongside it. A sample of the fuel used for the testing was analyzed and the resulting specifications are presented in the appendix, Table A1.

\section{Engine and Vehicle Parameters Measurement}

It was desired to understand the impact of close platooning of other engine and vehicle systems that could have negative unintended consequences such as engine cooling and selective catalytic reduction (SCR) exhaust aftertreatment performance. It was also of interest to evaluate whether the SAE J1939 fuel consumption rate reporting was accurate enough to replace gravimetric fuel measurement during investigative SAE Type II fuel consumption tests. The Isaac data loggers were recording the GPS location and SAE J1939 
channels at a $5-\mathrm{Hz}$ rate. A high resolution Race Technologies GPS Speedbox II with $0.02 \mathrm{~m} / \mathrm{s}$ accuracy was used to measure the test speeds accurately. The J1939 CAN bus channel list is presented in the appendix, Table A2.

\section{RESULTS}

\section{SAE Type II Fuel Consumption Results from Platooned Tractors}

\section{Gravimetric Fuel Savings Analysis}

All fuel consumption results for the $65 \mathrm{mph}, 65 \mathrm{k}$ GVW conditions are averaged from three baseline/test runs each. The remaining test conditions are averaged from two baseline/ test runs each due to budget considerations. Data analysis methods and the SAE spreadsheet recommended in SAE J1321 Fuel Consumption Test Procedure - Type II (2012) [12] were used during post processing to determine the $95 \%$ confidence interval $(\mathrm{Cl})$ and statistical significance for each test condition. The percent fuel saved and $95 \% \mathrm{Cl}$ for each test truck individually and as a "team" are shown in Table 3. The variable speed test demonstrated no statistically significant difference from baseline for either truck or the combined team result. Three test runs may have allowed a difference to be determined given this test's higher inherent variability. The lead truck in the $80 \mathrm{~K}$ lbs GVW condition and $65 \mathrm{mph}, 65 \mathrm{~K}$ lbs GVW, 75 -ft condition also resulted in no statistically significant differences. Values with no statistically significant difference from their baseline are italicized in Table 3 and are not discussed further.

Table 3. Percent fuel saved (gravimetric) of platooned tractors

\begin{tabular}{|c|c|c|c|c|c|c|}
\hline \multirow[b]{3}{*}{$\frac{\text { Test }}{\text { Conditions }}$} & \multicolumn{6}{|c|}{ Percent Fuel Saved (Gravimetric) } \\
\hline & \multicolumn{2}{|c|}{ Lead Truck } & \multicolumn{2}{|c|}{ Trailing Truck } & \multicolumn{2}{|c|}{ "Team" } \\
\hline & $\underline{\text { Nominal }}$ & $\underline{95 \% \mathrm{Cl}}$ & $\underline{\text { Nominal }}$ & $\underline{95 \% \mathrm{Cl}}$ & Nominal & $95 \% \mathrm{Cl}$ \\
\hline $\begin{array}{l}55 \mathrm{mph}, 65 \mathrm{k}, \\
30 \mathrm{ft}\end{array}$ & $4.33 \%$ & $0.70 \%$ & $8.38 \%$ & $1.03 \%$ & $6.38 \%$ & $0.28 \%$ \\
\hline $\begin{array}{l}55 \mathrm{mph}, 65 \mathrm{k}, \\
50 \mathrm{ft}\end{array}$ & $2.22 \%$ & $0.49 \%$ & $9.72 \%$ & $2.24 \%$ & $6.01 \%$ & $1.33 \%$ \\
\hline $\begin{array}{l}65 \mathrm{mph}, 65 \mathrm{k}, \\
20 \mathrm{ft}\end{array}$ & $5.28 \%$ & $0.34 \%$ & $2.81 \%$ & $0.71 \%$ & $4.04 \%$ & $0.52 \%$ \\
\hline $\begin{array}{l}65 \mathrm{mph}, 65 \mathrm{k}, \\
30 \mathrm{ft}\end{array}$ & $4.06 \%$ & $1.19 \%$ & $7.53 \%$ & $1.33 \%$ & $5.80 \%$ & $1.26 \%$ \\
\hline $\begin{array}{l}65 \mathrm{mph}, 65 \mathrm{k}, \\
40 \mathrm{ft}\end{array}$ & $2.69 \%$ & $0.99 \%$ & $9.10 \%$ & $0.71 \%$ & $5.91 \%$ & $0.84 \%$ \\
\hline $\begin{array}{l}65 \mathrm{mph}, 65 \mathrm{k}, \\
50 \mathrm{ft}\end{array}$ & $3.14 \%$ & $2.65 \%$ & $9.17 \%$ & $2.11 \%$ & $6.15 \%$ & $2.37 \%$ \\
\hline $\begin{array}{l}65 \mathrm{mph}, 65 \mathrm{k}, \\
75 \mathrm{ft}\end{array}$ & $1.69 \%$ & $2.35 \%$ & $9.39 \%$ & $1.93 \%$ & $5.53 \%$ & $2.12 \%$ \\
\hline $\begin{array}{l}70 \mathrm{mph}, 65 \mathrm{k}, \\
30 \mathrm{ft}\end{array}$ & $4.42 \%$ & $1.92 \%$ & $4.62 \%$ & $2.33 \%$ & $4.52 \%$ & $2.12 \%$ \\
\hline $\begin{array}{l}70 \mathrm{mph}, 65 \mathrm{k}, \\
50 \mathrm{ft}\end{array}$ & $2.23 \%$ & $0.35 \%$ & $8.36 \%$ & $1.44 \%$ & $5.31 \%$ & $0.90 \%$ \\
\hline $\begin{array}{l}\text { VAR, 65k, } \\
50 \mathrm{ft}\end{array}$ & $2.70 \%$ & $8.32 \%$ & $4.22 \%$ & $6.82 \%$ & $3.45 \%$ & $7.56 \%$ \\
\hline $\begin{array}{l}65 \mathrm{mph}, 80 \mathrm{k}, \\
50 \mathrm{ft}\end{array}$ & $0.55 \%$ & $3.58 \%$ & $6.67 \%$ & $4.84 \%$ & $3.68 \%$ & $2.07 \%$ \\
\hline
\end{tabular}

Statistically significant percent fuel savings with $95 \% \mathrm{Cl}$ bars for the lead platooned tractor-trailer are shown in Figure 6 . The lead tractor consistently demonstrated an improvement in average fuel consumption reduction as following distance decreased. The fuel savings ranged from $2.7 \%$ to $5.3 \%$ at $65 \mathrm{k}$ GVW, with a low point of $2.2 \%$ savings at both $55 \mathrm{mph} 50^{\prime}$ and $70 \mathrm{mph} 50^{\prime}$. The possible anomaly at $40 \mathrm{ft} / 50 \mathrm{ft}$ (shown in Figure 6) for the $65 \mathrm{mph}, 65 \mathrm{k}$ condition could be caused by changes in ambient conditions, wake structure from the lead vehicle, or uncertainty in the data. It may be due to those tests being conducted during a change in the weather consisting of colder temperatures, higher humidity, and lower wind speed than any other tests of that series. The possible mechanism of that change to the aerodynamic benefit for the lead vehicle has not yet been identified. Atmospheric conditions for all tests are presented in the appendix, Table A3. While the nominal test values at $40 \mathrm{ft} / 50 \mathrm{ft}$ show a distinct discontinuity, there is not sufficient statistical confidence in the tests to definitively state a difference, and as such it may just be part of the uncertainty in the data.

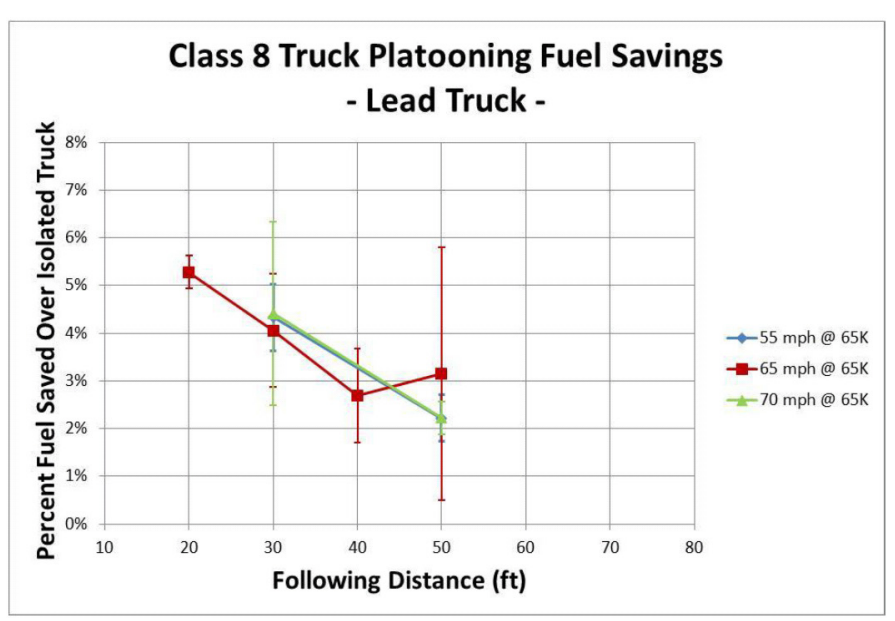

Figure 6. Lead platoon tractor percent fuel savings

Statistically significant percent fuel savings with 95\% Cl bars for the trailing platooned tractor-trailer are shown in Figure 7. Engine coolant temperatures on the trailing truck generally increased as following distances decreased, resulting in engine fan-on time as high as $19 \%$ for some closer following conditions compared to $0 \%-1 \%$ for longer following distances. Baseline tests never resulted in fan-on events as unobstructed airflow over the radiator kept the engine coolant temperatures cool enough not to require the fan. Engine fan usage correlates to reduced fuel savings on the trailing truck, but the magnitude of impact is currently undefined as such an aerodynamic effect may also be contributing to the lower fuel savings. The trailing truck achieved savings from $2.8 \%$ to $9.7 \%$; tests with no fan-on time had savings of $8.4 \%$ to $9.7 \%$. Tests at $55 \mathrm{mph}$ and $65 \mathrm{mph}$ with no fan-on events still demonstrated a slight downward trend in nominal average savings with shorter following distances, which could be due to some aerodynamic effects or uncertainty in the data. The $80 \mathrm{~K}$ lbs GVW condition lowered the fuel consumption reduction by $2.5 \%$ as compared to the $65 \mathrm{k}$ GVW $65 \mathrm{mph} 50 \mathrm{ft}$ following distance test set, resulting in a $6.7 \%$ reduction. 


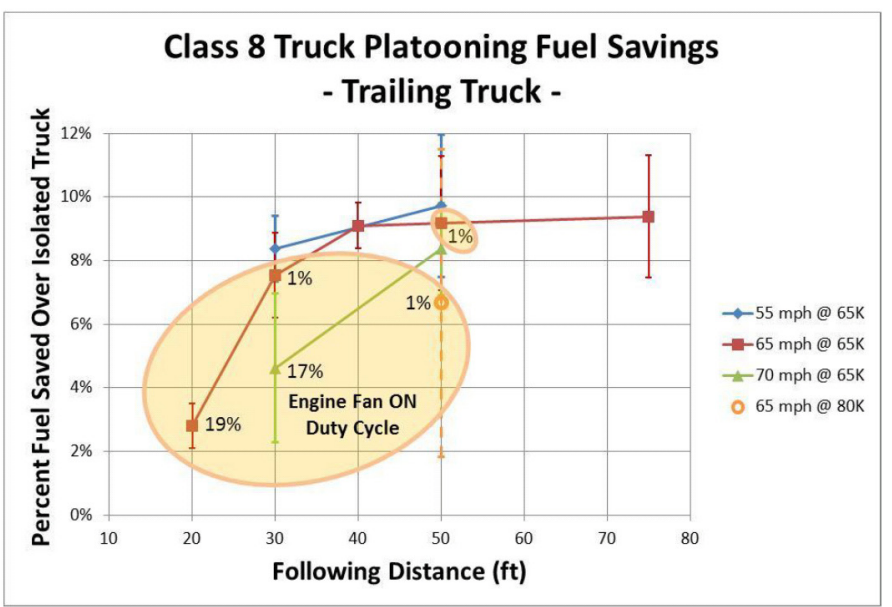

Figure 7. Trailing platoon tractor percent fuel savings

Statistically significant percent fuel savings with $95 \% \mathrm{Cl}$ bars for the team of two platooned tractor-trailers are shown in Figure 8 . Team fuel savings were determined by summing both the leading and trailing vehicle fuel consumption to consider them as one vehicle. The resulting values ranged from $3.7 \%$ to $6.4 \%$ with the best combined result documented for $55 \mathrm{mph}$, $30 \mathrm{ft}$ following distance, $65 \mathrm{k}$ GVW. The nominal percent savings at $70 \mathrm{mph}$ were lower than at $55 \mathrm{mph}$ and $65 \mathrm{mph}$, which does not agree with what would be predicted by the road load equation, but the differences are within the $95 \% \mathrm{Cl}$ of the $55 \mathrm{mph}$ and $65 \mathrm{mph}$ results so may be due to uncertainty in the data. The $80 \mathrm{~K}$ Ibs GVW condition negatively impacted fuel saved percent as well, resulting in the lowest combined nominal savings. Closer following distances caused the engine fan on the trailing truck to engage, which negatively impacted fuel savings. Test conditions that experienced no fan-on events had nominal results that ranged in team fuel saved from $5.3 \%$ to $6.4 \%$ for the combined pair of vehicles.

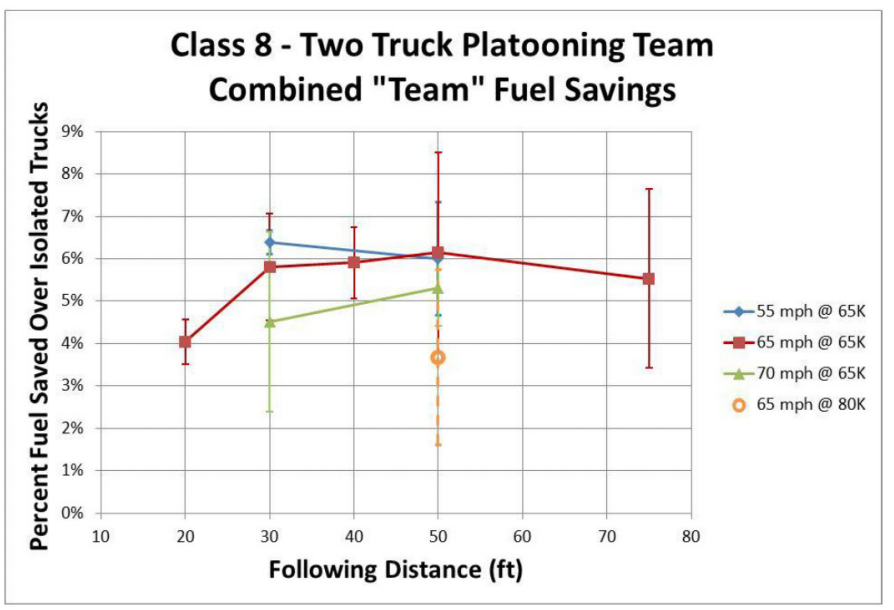

Figure 8. Platoon team percent fuel savings

\section{Ambient Conditions Effects}

Testing took place over a period of 3 weeks, with tests conducted throughout the day and night, resulting in a wide range of observed ambient conditions. For example, average wind speeds over the course of a test ranged from $2 \mathrm{mph}$ to $11.7 \mathrm{mph}$. Average temperatures ranged from $13^{\circ} \mathrm{C}$ to $32^{\circ} \mathrm{C}$. Relative humidity ranged from $17 \%$ to $88 \%$. The test set at 65 $\mathrm{mph}, 65 \mathrm{~K} \mathrm{Ibs} \mathrm{GVW}$ and $40 \mathrm{ft}$ following distance took place with the lowest wind and lowest temperatures of all baseline and test sets. The test set at $65 \mathrm{mph}, 65 \mathrm{~K} \mathrm{lbs} \mathrm{GVW}$ and $50 \mathrm{ft}$ following distance took place with the highest wind. An anomaly in the fuel consumption savings results for the lead vehicle occurs at either $40 \mathrm{ft}$ or $50 \mathrm{ft}$. Higher wind speeds could have increased the savings demonstrated by the lead vehicle at $50 \mathrm{ft}$ or the colder temperatures and low winds could have reduced the savings at $40 \mathrm{ft}$ (or a combination of both). To counter the changing ambient conditions, baseline sets preceded test sets for each vehicle speed / GVW condition and the $65 \mathrm{mph}, 65 \mathrm{~K}$ lbs GVW condition had two baseline sets to cover the five following distance tests. Atmospheric conditions for all tests are presented in the appendix, Table A3.

\section{J1939 Analysis Results}

\section{Fuel Consumption}

The $\mathrm{J} 1939$ reported fuel rate was recorded at a $5-\mathrm{Hz}$ rate and then integrated to determine aggregate fuel consumption for each test. The results were compared to the gravimetric fuel consumption measurement for each test to evaluate whether J1939 CAN bus reported fueling information could be used in place of gravimetric analysis in future fuel consumption studies. Across the 41 baseline and test condition runs performed, analysis of the CAN-reported fuel consumption values compared to the gravimetric values resulted in a remarkably consistent error observed across each of the vehicles, with the average error value being unique. The fuel consumed by all three vehicles on all tests in this program was underestimated by the $\mathrm{J} 1939$ approach. Errors on the three vehicles ranged from $-0.6 \%$ to $-7.1 \%$ with vehicle-level standard deviation of error of less than $1.4 \%$. Table 4 shows the range of error for each vehicle; run by run fuel consumption by each method is presented in the appendix, Table A4.

Table 4. SAE J1939 fuel consumption percent error

\begin{tabular}{|l|c|c|c|}
\hline & $\begin{array}{c}\text { Lead } \\
\text { Truck } \\
\text { Error }\end{array}$ & $\begin{array}{c}\text { Trailing } \\
\text { Truck } \\
\text { Error }\end{array}$ & $\begin{array}{c}\text { Control } \\
\text { Truck } \\
\text { Error }\end{array}$ \\
\hline Max Error & $-7.1 \%$ & $-6.4 \%$ & $-5.9 \%$ \\
\hline Average Error & $-6.1 \%$ & $-4.6 \%$ & $-3.6 \%$ \\
\hline Minimum Error & $-4.6 \%$ & $-3.3 \%$ & $-0.6 \%$ \\
\hline Std Dev of Error & $0.76 \%$ & $0.62 \%$ & $1.38 \%$ \\
\hline
\end{tabular}




\section{Trailing Tractor Coolant and Intake Air Temperature}

The J1939 CAN bus reported coolant and intake air temperatures were examined to evaluate the observed engine fan effects on the fuel savings on the trailing tractor. The temperatures were analyzed using the same SAE J1321 T/C ratio analysis prescribed for analyzing fuel consumption. While this is not a normal application for this analysis, this method was chosen as it accounted for the test-to-test weather variations well. Table 5 lists the percent changes in average and maximum temperatures seen over each test series as compared to the fuel savings demonstrated and engine fan duty cycle seen. Figure 9 shows the relationship between coolant temps, fan duty cycle, and fuel savings achieved. A rise of between $7 \%$ and $8 \%$ in average coolant temperature appears to be the point at which the fan may come on. Intake air temperatures were not the primary driver of the fan engagement and as such had poor correlation and so are not shown here.

Table 5. Average and maximum coolant and intake air temperature changes observed on the trailing tractor over each test series

\begin{tabular}{|l|c|c|c|c|c|c|}
\hline $\begin{array}{c}\text { Test } \\
\text { Conditions }\end{array}$ & $\begin{array}{c}\text { Fuel } \\
\text { Savings }\end{array}$ & $\begin{array}{c}\text { Coolant } \\
\text { Temp } \\
\text { Avg }\end{array}$ & $\begin{array}{c}\text { Coolant } \\
\text { Temp } \\
\text { Max }\end{array}$ & $\begin{array}{c}\text { Intake } \\
\text { Air } \\
\text { Temp } \\
\text { Avg }\end{array}$ & $\begin{array}{c}\text { Intake } \\
\text { Air } \\
\text { Temp } \\
\text { Max }\end{array}$ & $\begin{array}{c}\text { Engine } \\
\text { Fan } \\
\text { Duty } \\
\text { Cycle }\end{array}$ \\
\hline $\begin{array}{l}65 \mathrm{mph}, \\
65 \mathrm{k}, 75 \mathrm{ft}\end{array}$ & $9.4 \%$ & $1.5 \%$ & $2.6 \%$ & $0.2 \%$ & $-4.4 \%$ & $0 \%$ \\
\hline $\begin{array}{l}65 \mathrm{mph}, \\
65 \mathrm{k}, 50 \mathrm{ft}\end{array}$ & $9.2 \%$ & $4.9 \%$ & $7.0 \%$ & $4.6 \%$ & $9.0 \%$ & $1 \%$ \\
\hline $\begin{array}{l}65 \mathrm{mph}, \\
65 \mathrm{k}, 40 \mathrm{ft}\end{array}$ & $9.1 \%$ & $0.4 \%$ & $1.5 \%$ & $6.7 \%$ & $2.3 \%$ & $0 \%$ \\
\hline $\begin{array}{c}\text { Test } \\
\text { Conditions }\end{array}$ & $\begin{array}{c}\text { Fuel } \\
\text { Savings }\end{array}$ & $\begin{array}{c}\text { Coolant } \\
\text { Temp } \\
\text { Avg }\end{array}$ & $\begin{array}{c}\text { Coolant } \\
\text { Temp } \\
\text { Max }\end{array}$ & $\begin{array}{c}\text { Intake } \\
\text { Air } \\
\text { Temp } \\
\text { Avg }\end{array}$ & $\begin{array}{c}\text { Intake } \\
\text { Air } \\
\text { Temp } \\
\text { Max }\end{array}$ & $\begin{array}{c}\text { Engine } \\
\text { Fan } \\
\text { Duty } \\
\text { Cycle }\end{array}$ \\
\hline $\begin{array}{l}65 \mathrm{mph}, \\
65 \mathrm{k}, 30 \mathrm{ft}\end{array}$ & $7.5 \%$ & $7.0 \%$ & $10.7 \%$ & $0.8 \%$ & $11.8 \%$ & $1 \%$ \\
\hline $\begin{array}{l}65 \mathrm{mph}, \\
65 \mathrm{k}, 20 \mathrm{ft}\end{array}$ & $2.8 \%$ & $8.4 \%$ & $12.4 \%$ & $-2.4 \%$ & $13.2 \%$ & $19 \%$ \\
\hline $\begin{array}{l}55 \mathrm{mph}, \\
65 \mathrm{k}, 50 \mathrm{ft}\end{array}$ & $9.7 \%$ & $-0.3 \%$ & $-0.6 \%$ & $-22.0 \%$ & $-14.0 \%$ & $0 \%$ \\
\hline $\begin{array}{l}55 \mathrm{mph}, \\
65 \mathrm{k}, 30 \mathrm{ft}\end{array}$ & $8.4 \%$ & $0.2 \%$ & $1.7 \%$ & $-9.5 \%$ & $0.4 \%$ & $0 \%$ \\
\hline $\begin{array}{l}70 \mathrm{mph}, \\
65 \mathrm{k}, 50 \mathrm{ft}\end{array}$ & $8.4 \%$ & $1.0 \%$ & $1.6 \%$ & $5.8 \%$ & $1.7 \%$ & $0 \%$ \\
\hline $\begin{array}{l}70 \mathrm{mph}, \\
65 \mathrm{k}, 30 \mathrm{ft}\end{array}$ & $4.6 \%$ & $8.5 \%$ & $9.3 \%$ & $24.3 \%$ & $22.4 \%$ & $17 \%$ \\
\hline $\begin{array}{l}\text { VAR, 65k, } \\
50 \mathrm{ft}\end{array}$ & $4.2 \%$ & $6.6 \%$ & $9.4 \%$ & $0.9 \%$ & $9.6 \%$ & $3 \%$ \\
\hline $\begin{array}{l}65 \mathrm{mph}, \\
80 \mathrm{~K}, 50 \mathrm{ft}\end{array}$ & $6.7 \%$ & $1.3 \%$ & $0.9 \%$ & $-10.8 \%$ & $-4.1 \%$ & $1 \%$ \\
\hline
\end{tabular}

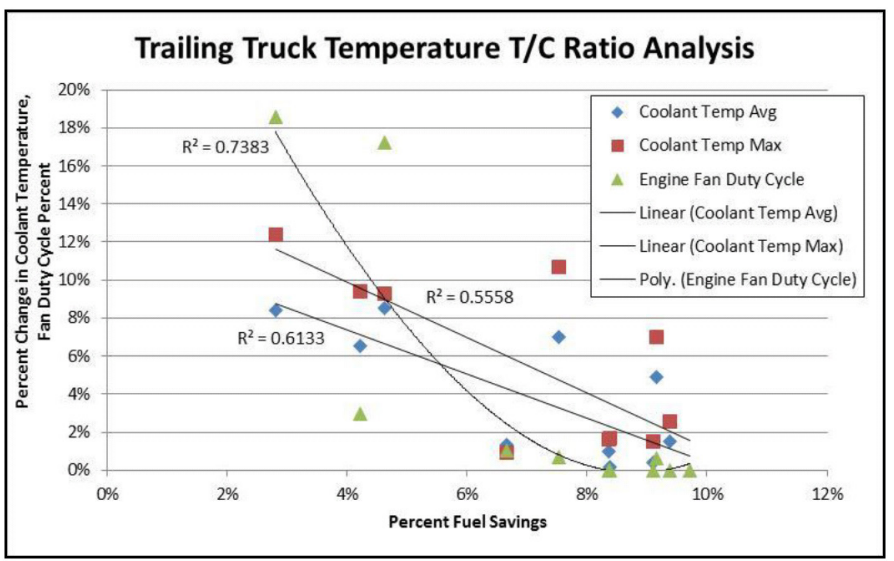

Figure 9. Trailing tractor coolant temperature analysis

\section{DISCUSSION}

While previous studies have set expectations for platooning tractor-trailers to achieve fuel savings above $10 \%$, the findings of the current study are more modest, but still impressive. Maximum fuel savings observed as part of this experiment were $5.3 \%$ and $9.7 \%$ for the lead and trailing trucks, respectively. It should be noted that these maximums were not achieved at the same test configuration. However, the vehicle combinations of a previous study [1] relied on older tractors and trailers without side skirts, which would not have had coefficient of drag (Cd) values near the EPA SmartWay tractors and trailer side skirt designs that are becoming common on U.S. interstates today and that were studied in this test series. Some previous studies [른 $\underline{3}, \underline{4}]$ utilized cab-over designs not currently common in the United States, which may respond differently to the complex aerodynamics of platooning. All of these studies [1, 2, $\underline{3}, \underline{4}$ ] also took place at road speeds of 45-55 mph, which are also not common for a line haul application in the United States and may simplify the aerodynamics associated with platooning. Another study []] examined higher vehicle mass than studied in this paper. The results demonstrated lower maximum savings, supporting the trend seen with mass.

The road load equation that governs the force required to move a tractor-trailer combination at constant speed neglecting road grade and wind variables is:

$$
F=1 / 2^{*} C d A^{*} \rho^{*} V^{2}+C R R^{*} m^{*} g
$$

Platooning, from a fuel consumption perspective, is not as straightforward as adjusting the Cd term in the same manner as the SmartWay aerodynamic aid systems are designed to address. The dynamic interaction between the two vehicles may also affect dynamic pressure, Reynolds number, flow direction, turbulence, and wake structure experienced by the platooned vehicle pair (or one of the pair). The tests demonstrated higher average percent fuel savings at lower speeds, which is opposite what would be predicted by the $\mathrm{V}^{2}$ term if only $\mathrm{Cd}$ is being affected by platooning. More study is needed to fully understand the complex aerodynamic interaction between platooned tractor-trailer combinations at highway speeds. It is possible that testing these vehicles below $55 \mathrm{mph}$ could have produced results similar to other studies, but they would not have been applicable to the current line haul environment in the United States today and what is expected in the future. It is also possible that testing at lower vehicle mass (or empty trailer) would have produced results similar to other studies, but it would not have conformed to the EPA SmartWay program test trailer and cargo weights for measuring fuel economy improvement [13].

The following distances tested equate to a 0.2 second to 0.8 second time gap between the vehicles at $65 \mathrm{mph}$ ( 0.3 to 0.5 second at $70 \mathrm{mph}$ ), which could not be manually performed in a safe way on public roads on long duration trips. However, it is not known how closely trucks routinely follow each other on public roads today. Results failed to demonstrate at what 
following distance the benefit to the trailing vehicle begins to diminish. Further study is needed to identify at what distance the benefit to the trailing vehicle approaches zero and whether trucks today are manually following at distances where platooning effects could be observed.

\section{SUMMARY/CONCLUSIONS}

The results of this study clearly indicate an opportunity for significant fuel savings through platooning technology in line haul applications. Some observations include:

- $\quad$ Platooning can result in significant fuel savings for both a leading (up to $5.3 \%$ ) and a trailing (up to $9.7 \%$ ) Class 8 vehicle.

- Engine coolant temperature needs to be monitored / addressed for the trailing vehicle to maximize the fuel savings for the vehicle pair by avoiding fan-on situations.

- Atmospheric conditions may play a strong role in the savings attainable due to the reduced air flow across the radiator induced by vehicle speed on the trailing vehicle. Hot days may require greater distance and possibly reduced savings without some specific platooning aerodynamic aid addressing the air flow across the radiator needs of the trailing vehicle while cooler ambient temperatures may allow for greater percent fuel savings by allowing closer following distances with less risk of fan-on.

- Heavy loads will affect the percent savings from platooning but still result in significant fuel savings, especially considering that heavily loaded vehicles consume fuel at a higher rate.

- Because the technology is expected to require a modest investment, the "team" savings of $6.4 \%$ on a pair of vehicles could end up with an attractive return on investment (ROI) for the fleet without reducing safety by attempting to follow closely under driver control.

- Additional study is necessary to reduce uncertainty about what combination of conditions offers the most advantageous platooning configuration.

\section{FUTURE WORK}

There are many questions still to be answered about the platooning of Class 8 tractor-trailer combinations. Some future research needs to be considered are:

- $\quad$ Collecting more data points/test sets to extrapolate the trends seen here and expand to greater following distances are desired to clarify the optimum configuration under differing atmospheric conditions. This work could also possibly be done with extensive computational fluid dynamics modeling.

- $\quad$ Testing platoons consisting of more than two tractor-trailer combinations or a combination of tractor-trailer and lightduty vehicles over a range of speeds, following distances, and loads.
- Identifying what percent of national line haul miles would be conducive to platooning. As observed here, while a pair of platooned tractor-trailers can save close to $6 \%$ on fuel consumption, the realistic in-use national savings will be less depending on the percent of time the system is able to be activated. This may depend on the logistics of routing vehicles from the same fleet together, opportunities to identify other, non-affiliated vehicles on the highway employing this technology as well as traffic and weather conditions that allow it to be employed.

- Designing aerodynamic aids specific to platooning that may be different than for an isolated truck or that may possibly address the loss of cooling airflow over the radiator for the trailing tractor to allow closer following without engine fan engagement.

\section{REFERENCES}

1. Browand, F., McArthur, J., and Radovich, C., "Fuel Saving Achieved in the Field Test of Two Tandem Trucks," California PATH Research Report UCB-ITS-PRR-2004-20, 2004.

2. Alam, al A., Gattami, A., and Johansson, K.H., "An Experimental Study on the Fuel Reduction Potential of Heavy Duty Vehicle Platooning," 2010 13th International IEEE Annual Conference on Intelligent Transportation Systems, September 19-22, 2010.

3. Tsugawa, S., Kato, S., and Aoki, K., "An Automated Truck Platoon for Energy Saving," 2011 IEEE/RSJ International Conference on Intelligent Robots and Systems, September 25-30, 2011.

4. SAE International, Ashley, S., "Truck Platoon Demo Reveals $15 \%$ Bump in Fuel Economy," http://articles.sae.org/11937/ May 2013.

5. Continental Tire the Americas, LLC; Uvalde Proving Grounds; 6969 F.M. Road 117 P.O. Box 480 Uvalde, Texas 78802; http:// www.uvaldeprovinggrounds.com/ (830) 591-7000.

6. SAE International Surface Vehicle Recommended Practice, "Joint TMC/SAE Fuel Consumption Test Procedure - Type II," SAE Standard J1321, Rev. Oct. 1986.

7. SAE International Surface Vehicle Recommended Practice, "Vehicle Application Layer," SAE Standard J1939/71, Rev. Apr. 2014.

8. U.S. Environmental Protection Agency, "Smartway," http://www. epa.gov/smartwayl, Jul. 2014.

9. Peloton Technology Inc., http://www.peloton-tech.com/.

10. Research and Innovative Technology Administration (RITA), U.S. Department of Transportation (US DOT) http://www.its.dot.gov/ DSRC/

11. DieselNet, "Emissions Test Cycles, Heavy Heavy-Duty Diesel Truck (HHDDT) Schedule," https://www.dieselnet.com/standards/ cycles/hhddt.php.

12. SAE International Surface Vehicle Recommended Practice, "Fuel Consumption Test Procedure - Type II," SAE Standard J1321, Rev. Feb. 2012.

13. U.S. Environmental Protection Agency, "Interim Test Method for Verifying Fuel-Saving Components for SmartWay: Modifications to SAE J1321," http://www.epa.gov/smartway/forpartners/ documents/verified/420f12022.pdf, May 2012.

\section{CONTACT INFORMATION}

michael.lammert@nrel.gov

National Renewable Energy Laboratory

15013 Denver West Parkway

Golden, CO 80401-3305

(303) 275-4067 


\section{ACKNOWLEDGMENTS}

This work was supported by the U.S. Department of Energy (DOE) Advanced Vehicle Testing Activity through Intertek Testing Services, North America and would not have been possible without the generous donation of time and vehicles from Peloton, Inc. The authors wish to thank Lee Slezak and David Anderson at the Department of Energy and Josh Switkes at Peloton for their support.

\section{DEFINITIONS/ABBREVIATIONS}

CAN - controller area network

CARB - California Air Resources Board

CFD - Computational fluid dynamics

Cd - coefficient of drag

$\mathrm{Cl}$ - confidence interval

Crr - coefficient of rolling resistance

DOE - Department of Energy

DSRC - Dedicated Short-Range Communication

DPF - diesel particulate filter

EPA - U.S. Environmental Protection Agency

GPS - global positioning system

GVW - gross vehicle weight

HHDDT - Heavy Heavy-Duty Diesel Truck

NEDO - New Energy and Industrial Technology Development Organization

NREL - National Renewable Energy Laboratory

PATH - Partners for Advanced Transportation Technology

ROI - return on investment

SAE - Society of Automotive Engineers International

SCR - selective catalytic reduction

V2V - Vehicle-to-vehicle 
APPENDIX

Table A1. Diesel fuel test results

\begin{tabular}{|c|c|c|}
\hline Method & Unit & Result \\
\hline \multicolumn{3}{|l|}{ D1319 } \\
\hline Aromatics & $\%$ & 36.1 \\
\hline Olefins & $\%$ & 1.2 \\
\hline Saturates & $\%$ & 62.7 \\
\hline \multicolumn{3}{|l|}{ ASTM D445 @40C } \\
\hline Viscosity & & 2.186 \\
\hline \multicolumn{3}{|l|}{ ASTM D482 } \\
\hline Ash Content & mass $\%$ & $<0.001$ \\
\hline \multicolumn{3}{|l|}{ ASTM D5453 } \\
\hline Sulfur & ppm & 4.0 \\
\hline \multicolumn{3}{|l|}{ ASTM D86 } \\
\hline IBP & $\operatorname{deg} \mathrm{F}$ & 345.8 \\
\hline Evap_5 & $\operatorname{deg} \mathrm{F}$ & 380.7 \\
\hline Evap 10 & $\operatorname{deg} F$ & 391.4 \\
\hline Evap_15 & $\operatorname{deg} \mathrm{F}$ & 402.6 \\
\hline Evap 20 & $\operatorname{deg} \mathrm{F}$ & 413.0 \\
\hline Evap_30 & $\operatorname{deg} \mathrm{F}$ & 433.3 \\
\hline Evap_40 & $\operatorname{deg} \mathrm{F}$ & 454.1 \\
\hline Evap_50 & $\operatorname{deg} F$ & 475.6 \\
\hline Evap_60 & $\operatorname{deg} \mathrm{F}$ & 499.2 \\
\hline Evap_70 & $\operatorname{deg} F$ & 524.3 \\
\hline Evap_80 & $\operatorname{deg} \mathrm{F}$ & 553.8 \\
\hline Evap_90 & $\operatorname{deg} \mathrm{F}$ & 592.5 \\
\hline Evap_95 & $\operatorname{deg} F$ & 624.8 \\
\hline FBP & $\operatorname{deg} \mathrm{F}$ & 652.0 \\
\hline Recoverd & $\mathrm{mL}$ & 98.0 \\
\hline Residue & $\mathrm{mL}$ & 1.4 \\
\hline Loss & $\mathrm{mL}$ & 0.6 \\
\hline PCorrlBP & $\operatorname{deg} \mathrm{F}$ & 345.8 \\
\hline PCorrFBP & $\operatorname{deg} \mathrm{F}$ & 652.0 \\
\hline PCorrD10 & $\operatorname{deg} \mathrm{F}$ & 392.5 \\
\hline PCorrD50 & $\operatorname{deg} F$ & 477.0 \\
\hline PCorrD90 & $\operatorname{deg} \mathrm{F}$ & 596.0 \\
\hline PCorrD95 & $\operatorname{deg} \mathrm{F}$ & 631.2 \\
\hline UCorRevd & $\mathrm{mL}$ & 97.9 \\
\hline UCorLoss & $\mathrm{mL}$ & 0.7 \\
\hline \multicolumn{3}{|l|}{ ASTM D93 } \\
\hline \multirow[t]{2}{*}{ Flash Point } & $\operatorname{deg} F$ & 141 \\
\hline & $\operatorname{deg} \mathrm{C}$ & 61 \\
\hline DCN & & 55.8 \\
\hline Density & $\mathrm{g} / \mathrm{cm} 3$ & 0.8158 \\
\hline Gross heat of Combustion D240 & $\mathrm{J} / \mathrm{g}$ & 46,215 \\
\hline FAME by IR & & $0 \%$ biodiesel \\
\hline $\mathrm{CP}$ & $\mathrm{C}$ & -12.7 \\
\hline
\end{tabular}


Table A2. SAE J1939 data logging channel list

\begin{tabular}{|c|c|c|c|c|c|}
\hline Data Channel Name & Data Channel Name & Acronym & PGN\# & SPN\# & Units \\
\hline Transmission Output Shaft Speed & TransOutputShaftSpeed_1 & ETC1 & 61442 & 191 & RPM \\
\hline Transmission Input Shaft Speed & TransInputShaftSpeed_1 & ETC1 & 61442 & 161 & RPM \\
\hline Accelerator Pedal Position 1 & AccelPedalPos1 & EEC2 & 61443 & 91 & $\%$ \\
\hline Engine Percent Load At Current Speed & EngPercentLoadAtCurrentSpeed & EEC2 & 61443 & 92 & $\%$ \\
\hline Actual Maximum Available Engine - Percent Torque & ActMaxAvailEngPercentTorque & EEC2 & 61443 & 3357 & $\%$ \\
\hline Driver's Demand Engine - Percent Torque & DriversDemandEngPercentTorque & EEC1 & 61444 & 512 & $\%$ \\
\hline Actual Engine - Percent Torque & ActualEngPercentTorque & EEC1 & 61444 & 513 & $\%$ \\
\hline Engine Speed & EngSpeed & EEC1 & 61444 & 190 & RPM \\
\hline Transmission Selected Gear & TransSelectedGear_1 & ETC2 & 61445 & 524 & Gear \\
\hline Transmission Current Gear & TransCurrentGear_-1 & ETC2 & 61445 & 523 & Gear \\
\hline Engine Exhaust Gas Recirculation 1 (EGR1) Mass Flow Rate & EngExhstGsRcrcltionMassFlowRate & EGF1 & 61450 & 2659 & $\mathrm{~kg} / \mathrm{hr}$ \\
\hline Engine Intake Air Mass Flow Rate & EngInletAirMassFlowRate & EGF1 & 61450 & 132 & $\mathrm{~kg} / \mathrm{hr}$ \\
\hline Diesel Particulate Filter Lamp Command & DieselParticulateFilterLampCmd & DPFC1 & 64892 & 3697 & - \\
\hline Diesel Particulate Filter Passive Regeneration Status & DsIPrtclPssvRgnrtionStatus & DPFC1 & 64892 & 3699 & - \\
\hline Diesel Particulate Filter Active Regeneration Status & DsIPrtclActvRgnitionStatus & DPFC1 & 64892 & 3700 & - \\
\hline Diesel Particulate Filter Status & DieselParticulateFilterStatus & DPFC1 & 64892 & 3701 & - \\
\hline Exhaust System High Temperature Lamp Command & ExhaustSystemHighTempLampCmd & DPFC1 & 64892 & 3698 & - \\
\hline Diesel Particulate Filter Active Regeneration Forced Status & DsIPrtclActvRgnitionFrcdStatus & DPFC1 & 64892 & 4175 & - \\
\hline Aftertreatment 1 Diesel Particulate Filter Outlet Gas Temperature & Aftrtrtmnt1PrtcltTrpOtttGasTemp & AT10G2 & 64947 & 3246 & $\operatorname{deg} \mathrm{C}$ \\
\hline Aftertreatment Exhaust Gas Temp & Aftertreatment1ExhaustGasTemp1 & AT1IG2 & 64948 & 3241 & $\operatorname{deg} C$ \\
\hline Referenced Torque & ReferenceEngineTorque & EC1 & 65251 & 544 & $\mathrm{Nm}$ \\
\hline Red Stop Lamp (engine) & EngRedStopLampData & DLCD1 & 64773 & 5095 & - \\
\hline Amber Warning Lamp (engine) & EngAmberWarningLampData & DLCD1 & 64773 & 5094 & - \\
\hline Protect Lamp (engine) & EngProtectLampData & DLCD1 & 64773 & 5093 & - \\
\hline Nominal Friction - Percent Torque & NominalFrictionPercentTorque & EEC3 & 65247 & 514 & $\%$ \\
\hline Engine Coolant Temperature & EngCoolantTemp & ET1 & 65262 & 110 & $\operatorname{deg} \mathrm{C}$ \\
\hline Engine Fuel Temperature 1 & EngFuelTemp & ET1 & 65262 & 174 & $\operatorname{deg} C$ \\
\hline Engine Oil Temperature 1 & EngOilTemp1 & ET1 & 65262 & 175 & $\operatorname{deg} C$ \\
\hline Engine Intercooler Temperature & EngIntercoolerTemp & ET1 & 65262 & 52 & $\operatorname{deg} C$ \\
\hline Engine Fuel Delivery Pressure & EngFuelDeliveryPress & EFLP1 & 65263 & 94 & $\mathrm{kPa}$ \\
\hline Engine Oil Pressure & EngOilPress & EFLP1 & 65263 & 100 & $\mathrm{kPa}$ \\
\hline Wheel-Based Vehicle Speed & WheelBasedVehicleSpeed & CCVS & 65265 & 84 & $\mathrm{~km} / \mathrm{h}$ \\
\hline Brake Switch & BrakeSwitch & CCVS & 65265 & 597 & - \\
\hline Engine Fuel Rate & EngFuelRate & LFE & 65266 & 183 & $\mathrm{l} / \mathrm{h}$ \\
\hline Barometric Pressure & BarometricPress & AMB & 65269 & 108 & $\mathrm{kPa}$ \\
\hline Ambient Air Temperature & AmbientAirTemp & AMB & 65269 & 171 & $\operatorname{deg} C$ \\
\hline Engine Air Intake Temperature & EngAirlnletTemp & AMB & 65269 & 172 & $\operatorname{deg} C$ \\
\hline Engine Intake Manifold 1 Pressure & EngTurboBoostPress & IC1 & 65270 & 102 & $\mathrm{kPa}$ \\
\hline Engine Intake Manifold 1 Temperature & EngIntakeManifold1Temp & IC1 & 65270 & 105 & $\operatorname{deg} \mathrm{C}$ \\
\hline Engine Air Intake Pressure & EngAirlnletPress & IC1 & 65270 & 106 & $\mathrm{kPa}$ \\
\hline Engine Exhaust Gas Temperature & EngExhaustGasTemp & IC1 & 65270 & 173 & $\operatorname{deg} \mathrm{C}$ \\
\hline Engine Oil Temperature 2 & EngOilTemp2 & ET2 & 65188 & 1135 & $\operatorname{deg} C$ \\
\hline Engine Exhaust Gas Temperature - Left Manifold & EngExhaustGasTempLeftManifold & ET & 65031 & 2434 & $\operatorname{deg} C$ \\
\hline Engine Exhaust Gas Temperature - Right Manifold & EngExhaustGasTempRightManifold & ET & 65031 & 2433 & $\operatorname{deg} C$ \\
\hline Engine Exhaust Gas Average Temperature & EngExhaustGasTempAverage & EAl & 64851 & 4151 & $\operatorname{deg} C$ \\
\hline Diesel Oxidation Catalyst Intake Gas Temperature 1 & Aftrtrtmnt1DsIOxdtnCtlystDffPrss & A1DOC & 64800 & 4765 & $\operatorname{deg} C$ \\
\hline Diesel Oxidation Catalyst Exhaust Gas Temperature 1 & Aftrtrtmnt1DsIOxdtnCtlystlntkGsT & A1DOC & 64800 & 4766 & $\operatorname{deg} C$ \\
\hline Diesel Oxidation Catalyst Differential Pressure 1 & Aftrtrtmnt1DsIOxdtnCtlystOut|GsT & A1DOC & 64800 & 4767 & $\mathrm{kPa}$ \\
\hline Diesel Oxidation Catalyst Intake Gas Temperature 2 & Aftrtrtmnt2Ds|OxdtnCtlystlntkGsT & A2DOC & 64799 & 4771 & $\operatorname{deg} C$ \\
\hline Diesel Oxidation Catalyst Exhaust Gas Temperature 2 & Aftrtrtmnt2DsIOxdtnCtlystOut|GsT & A2DOC & 64799 & 4772 & $\operatorname{deg} C$ \\
\hline Diesel Oxidation Catalyst Differential Pressure 2 & Aftrtrtmnt2DslOxdtnCtlystDffPrss & A2DOC & 64799 & 4773 & $\mathrm{kPa}$ \\
\hline SCR Catalyst Intake Gas Temperature 1 & Aftrtrtmnt1SCRCtlystlntkGasTemp & A1SCREGT & 64830 & 4360 & $\operatorname{deg} C$ \\
\hline SCR Catalyst Exhaust Gas Temperature 1 & Aftrtrtmnt1SCRCtlysOut|GasTemp & A1SCREGT & 64830 & 4363 & $\operatorname{deg} C$ \\
\hline SCR Exhaust Gas Differential Pressure 1 & Aftrtrtmnt1SCRCtlysExhstGsDffPr & A1DCREGP & 64831 & 4358 & $\mathrm{kPa}$ \\
\hline SCR System State 1 & Aftertreatment1SCRSystemState & A1SCRDS1 & 61475 & 4332 & - \\
\hline SCR Diesel Exhaust Fluid Dosing Requested Quantity 1 & Aftrtrtmnt1SCRRqdDsngRgntQntity & A1SCRDSR1 & 61476 & 4348 & $\mathrm{~g} / \mathrm{hr}$ \\
\hline SCR 1 Diesel Exhaust Fluid Average Consumption & Aftrtrtmnt1SCRAvrgCtlystRgntCnsm & SCR1 & 64878 & 3826 & L/hr \\
\hline SCR Conversion Efficiency & Aftrtrtmnt1SCRCtlystCnvrsnEffcnc & SCR1 & 64878 & 4364 & $\%$ \\
\hline Diesel Exhaust Fluid Actual Dosing Quantity 1 & Aftrtrtmnt1SCRActIDsngRgntQntty & A1SCRDSI1 & 61475 & 4331 & $\mathrm{~g} / \mathrm{hr}$ \\
\hline Diesel Particulate Filter Differential Pressure & Aftrtrtmnt1DsPrtcltFltrDffPrss & AT1IMG & 64946 & 3251 & $\mathrm{kPa}$ \\
\hline Diesel Particulate Filter Intermediate Gas Temperature & Aftrtrtmnt1DsIPrtcltFItrInt_0001 & AT1IMG & 64946 & 3252 & $\operatorname{deg} C$ \\
\hline Engine Exhaust Gas Recirculation Temperature 1 & EngExhaustGasRecirculation1Temp & $\mathrm{ET} 2$ & 65188 & 4750 & $\operatorname{deg} C$ \\
\hline Aftertreatment 1 Outlet $\mathrm{NH} 3$ & Aftertreatment1OutletNH3 & A1SCRAI & 61477 & 4377 & $\mathrm{ppm}$ \\
\hline Aftertreatment 1 Outlet $\mathrm{NOx}$ & Aftertreatment1OutletNOx & AT1OF1 & 61455 & 3226 & $\mathrm{ppm}$ \\
\hline Aftertreatment 1 Intake NOx & Aftertreatment1 IntakeNOx & AT1IG1 & 61454 & 3216 & $\mathrm{ppm}$ \\
\hline
\end{tabular}


Table A3. Weather data

\begin{tabular}{|c|c|c|c|c|c|c|c|c|c|c|c|c|c|c|c|}
\hline 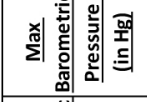 & $\begin{array}{l}\vec{d} \\
\stackrel{d}{d}\end{array}$ & & $\stackrel{\infty}{\infty}$ & 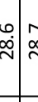 & & 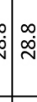 & $\mid \begin{array}{c}\infty \\
\stackrel{\infty}{\infty}\end{array}$ & 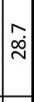 & 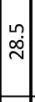 & 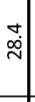 & $\begin{array}{llll}\infty & 1 \\
\infty & 0 \\
i & 0 & \end{array}$ & & 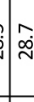 & & dִ \\
\hline 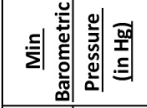 & 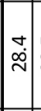 & & $\begin{array}{l}\infty \\
\stackrel{\sim}{\sim} \\
\infty\end{array}$ & & & în & $\stackrel{\infty}{\infty}_{\infty}^{\infty}$ & $\begin{array}{l}0 \\
\infty \\
\sim \\
\sim\end{array}$ & $\left.\mid \begin{array}{l}n \\
\substack{\infty \\
\sim}\end{array}\right]$ & 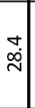 & & & 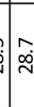 & & 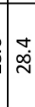 \\
\hline 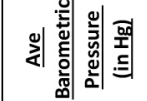 & 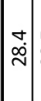 & & $\stackrel{\infty}{\infty}$ & & & 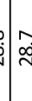 & $\stackrel{\infty}{\infty}$ & 命 & 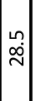 & 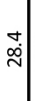 & 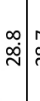 & & 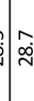 & & 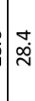 \\
\hline 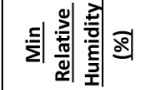 & \begin{tabular}{|l}
$\vec{j}$ \\
$\dot{g}$
\end{tabular} & & ¿. & \begin{tabular}{l|l}
$\dot{q}$ \\
$\dot{q}$
\end{tabular} & $\begin{array}{lll}0 \\
0\end{array}$ & $\dot{a}$ & 吕 & $\begin{array}{l}\text { g } \\
\dot{N}\end{array}$ & 望 & $\hat{i}$ & & & $\stackrel{n}{n}$ & & $\frac{0}{m}$ \\
\hline 릴 & $\stackrel{m}{n}$ & & مُ & & $\underset{\gamma}{a}$ & & I & $\begin{array}{l}u_{0} \\
\infty \\
\infty\end{array}$ & $\mid \begin{array}{l}0 \\
0 \\
0 \\
q\end{array}$ & 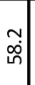 & & & 我 & & 方 \\
\hline 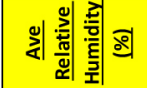 & $\begin{array}{l}0 \\
\dot{0} \\
i\end{array}$ & $\stackrel{0}{:}$ & $\stackrel{m}{\stackrel{m}{R}}$ & กิ่ & : & & 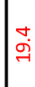 & 命 & $\left|\begin{array}{l}0 \\
\dot{m} \\
m\end{array}\right|$ & م્ & :ें & & b. & & $\stackrel{n}{g}$ \\
\hline 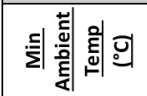 & $\hat{i}$ & $\vec{n}$ & $\stackrel{0}{\sim}$ & 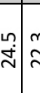 & $\begin{array}{rll}n & n & n \\
z & \end{array}$ & $n$ & i & m. & 吕 & $\hat{i}$ & กุ: & & $\stackrel{m}{g}$ & & $\frac{m}{m}$ \\
\hline 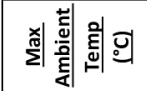 & $\stackrel{\substack{n \\
\infty}}{\sim}$ & & $\hat{m}$ & 它| & 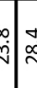 & $\stackrel{n}{s}$ & ف․ & în. & $\mid \begin{array}{l}\mid \vec{p} \\
\dot{p}\end{array}$ & $\stackrel{\sim}{\sim}$ & הี & & $\dot{n}$ & & 夜 \\
\hline 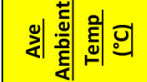 & $\stackrel{0}{\grave{i}}$ & iे & - & $\begin{array}{c}m \\
\text { ஸे }\end{array}$ & ن. & $\begin{array}{l}9 \\
0\end{array}$ & ì & $\begin{array}{l}\infty \\
\stackrel{2}{7} \\
\text { a }\end{array}$ & -7. & ì & ì & & 空 & & $\vec{m}$ \\
\hline 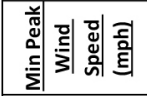 & $\stackrel{\infty}{i}$ & $\begin{array}{l}\stackrel{\sigma}{ } \\
\dot{\gamma}\end{array}$ & 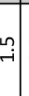 & \begin{tabular}{c|c}
$\infty$ \\
$\sigma$ \\
$\sigma$
\end{tabular} & t. & $\dot{b}$ & m. & $\begin{array}{l}m \\
\dot{\omega}\end{array}$ & $\stackrel{\vec{i}}{\mathrm{i}}$ & $\underset{f}{\sigma}$ & تُ & & $\prod_{m}^{\infty}$ & & 응 \\
\hline 丞| & $\stackrel{\dot{m}}{\dot{m}}$ & & ब. & $\stackrel{n}{\infty} \mid ?$ & 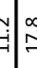 & $\because \sigma^{2}$ & & 离 & {$\left[\begin{array}{l}0 \\
\infty\end{array} \mid\right.$} & \begin{tabular}{l}
$\infty$ \\
$\vdots$ \\
\hdashline
\end{tabular} & $\begin{array}{c}m \\
\text { فे }\end{array}$ & & : & & : \\
\hline 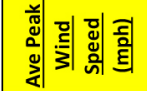 & 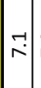 & . & ه্ণ & $\begin{array}{l}\text { : } \\
\end{array}$ & 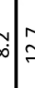 & $\dot{s}$ & 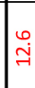 & $\begin{array}{c}\infty \\
\sigma \\
\sigma\end{array}$ & ثُ & & ๙ু & & 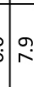 & & : \\
\hline 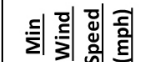 & $\overrightarrow{\mathrm{N}}$ & $\stackrel{m}{\stackrel{\sim}{*}}$ & $\stackrel{m}{-}$ & 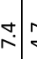 & 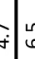 & : & 욱 & $\stackrel{m}{+}$ & ] & $\vec{F}$ & $\begin{array}{c}\stackrel{\leftrightarrow}{m} \\
\end{array}$ & & $\overbrace{m}$ & & $\underset{f}{\mathscr{S}}$ \\
\hline 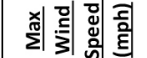 & $\dot{\sigma}$ & $\begin{array}{c}\sim \\
\infty \\
\infty\end{array}$ & $\stackrel{m}{m}$ & ㅇํㄹㅇㅢ & $=$ & 年 & $\underset{q}{m}$ & ت্ & $\stackrel{m}{\sim}$ & $\begin{array}{l}0 \\
\infty\end{array}$ & $\begin{array}{l}0 \\
\text { ît }\end{array}$ & & $\infty_{\infty}^{\infty}$ & & 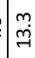 \\
\hline 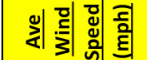 & 岂 & ન્- & ه্ণ & $\vec{\exists}$ & ọ & $\vec{m}$ & ذ্. & $\vec{\infty}$ & F & $\mid \begin{array}{c}m \\
\dot{b}\end{array}$ & 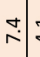 & & t: & & $\underset{\infty}{-\infty}$ \\
\hline 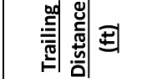 & ì & ळे & $q$ & ìn & $\Omega \ddot{c}$ & 品 & iे & ஸे & 总 & 임 & $i$ & & $1:$ & & : \\
\hline 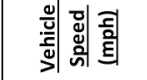 & 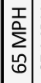 & 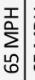 & 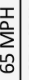 & $\sum_{\substack{x \\
\frac{1}{2}}}$ & & $\hat{\sum}$ & $\sum_{\text {出 }}^{T}$ & 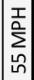 & 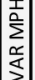 & $\sum_{\substack{1 \\
\vdots}}^{T}$ & 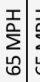 & & 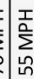 & & 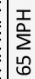 \\
\hline 窇 & $\left|\begin{array}{c}0 \\
0 \\
\omega \\
0\end{array}\right|$ & 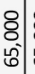 & 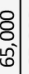 & 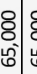 & مُ & $\mid \begin{array}{l}8 \\
0 \\
3 \\
0\end{array}$ & 这 & $\begin{array}{l}8 \\
8 \\
0 \\
0\end{array}$ & $\mid \begin{array}{l}0 \\
0 \\
0 \\
0 \\
1\end{array}$ & $\begin{array}{l}\text { o. } \\
\text { - } \\
\vdots\end{array}$ & $\begin{array}{l}8 \\
0 \\
0 \\
0\end{array}$ & & 3 & & (lo \\
\hline 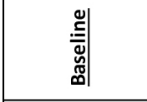 & 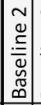 & 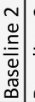 & 童 & 资 & & & & & & & & & & & \\
\hline $\begin{array}{l}0 \\
0\end{array}$ & 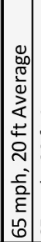 & 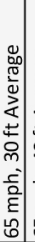 & 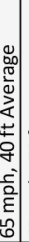 & 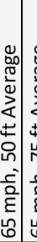 & 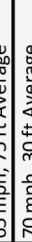 & 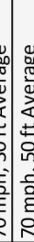 & 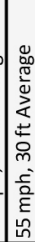 & 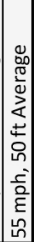 & 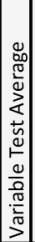 & 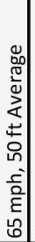 & 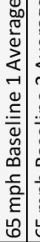 & 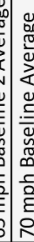 & 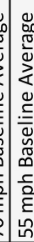 & 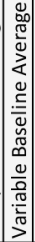 & 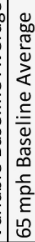 \\
\hline
\end{tabular}


Table A4. Fuel consumption results

\begin{tabular}{|c|c|c|c|c|c|c|c|c|c|c|c|c|c|}
\hline \multirow[b]{2}{*}{$\underline{\text { Test Description }}$} & \multirow[b]{2}{*}{ Baseline } & \multirow[b]{2}{*}{$\frac{\frac{\text { Vehicle }}{\text { GCVw }}}{\frac{\text { (lbs) }}{\text { lbs }}}$} & \multirow[b]{2}{*}{\begin{tabular}{|l|}
$\frac{\text { Vehicle }}{\text { Speed }}$ \\
(mph) \\
\end{tabular}} & \multirow[b]{2}{*}{$\mid$\begin{tabular}{|c|}
$\frac{\text { Trailing }}{\text { Distance }}$ \\
(ft)
\end{tabular}} & \multicolumn{3}{|c|}{ Gavimetric Result } & \multicolumn{3}{|c|}{ J1939 Result } & \multicolumn{3}{|c|}{ J1939 \% Error } \\
\hline & & & & & $\begin{array}{c}\underline{\text { Lead }} \\
\text { Iruck Gal }\end{array}$ & $\begin{array}{l}\text { Trailing } \\
\text { Truck Gal } \\
\end{array}$ & \begin{tabular}{|} 
Control \\
Truck Gal \\
\end{tabular} & $\begin{array}{l}\text { Lead } \\
\text { Truck Gal }\end{array}$ & $\begin{array}{c}\text { Trailing } \\
\text { Truck Gal }\end{array}$ & $\begin{array}{c}\text { Control } \\
\text { Truck Gal }\end{array}$ & $\begin{array}{l}\frac{\text { Lead }}{\text { Truck }} \\
\text { Error }\end{array}$ & $\frac{\frac{\text { Trailing }}{\text { Truck }}}{\frac{\text { Error }}{}}$ & $\begin{array}{l}\frac{\text { Control }}{\text { Truck }} \\
\text { Error }\end{array}$ \\
\hline $65 \mathrm{mph}, 20 \mathrm{ft}$ & Baseline 2 & 65,000 & $65 \mathrm{MPH}$ & $20^{\prime}$ & 8.00 & 8.28 & 8.91 & 7.48 & 7.90 & 8.52 & $-6.5 \%$ & $-4.6 \%$ & $-4.3 \%$ \\
\hline $65 \mathrm{mph}, 20 \mathrm{ft}$ & \begin{tabular}{|l|} 
Baseline 2 \\
\end{tabular} & 65,000 & $65 \mathrm{MPH}$ & $20^{\prime}$ & 8.06 & 8.34 & 8.97 & 7.53 & 7.94 & 8.59 & $-6.6 \%$ & $-4.8 \%$ & $-4.2 \%$ \\
\hline $65 \mathrm{mph}, 20 \mathrm{ft}$ & \begin{tabular}{|l|} 
Baseline 2 \\
\end{tabular} & 65,000 & $65 \mathrm{MPH}$ & $20^{\prime}$ & 8.07 & 8.31 & 9.00 & 7.54 & 7.91 & 8.63 & $-6.6 \%$ & $-4.9 \%$ & $-4.2 \%$ \\
\hline $65 \mathrm{mph}, 20 \mathrm{ft}$ Average & Baseline 2 & $\underline{65,000}$ & $65 \mathrm{MPH}$ & $\underline{\underline{20}}$ & 8.04 & 8.31 & 8.96 & 7.52 & 7.92 & 8.58 & $-6.5 \%$ & $-4.8 \%$ & $-4.2 \%$ \\
\hline $65 \mathrm{mph}, 30 \mathrm{ft}$ & Baseline 2 & 65,000 & $65 \mathrm{MPH}$ & $30^{\prime}$ & 8.26 & 8.02 & 9.08 & 7.72 & 7.65 & 8.74 & $-6.4 \%$ & $-4.6 \%$ & $-3.8 \%$ \\
\hline $65 \mathrm{mph}, 30 \mathrm{ft}$ & Baseline 2 & 65,000 & $65 \mathrm{MPH}$ & $30^{\prime}$ & 8.37 & 8.13 & 9.13 & 7.82 & 7.74 & 8.75 & $-6.5 \%$ & $-4.8 \%$ & $-4.1 \%$ \\
\hline $65 \mathrm{mph}, 30 \mathrm{ft}$ & Baseline 2 & 65,000 & $65 \mathrm{MPH}$ & $30^{\prime}$ & 8.62 & 8.35 & 9.54 & 8.06 & & 9.18 & $-6.5 \%$ & & $-3.8 \%$ \\
\hline $65 \mathrm{mph}, 30 \mathrm{ft}$ Average & Baseline 2 & $\underline{65,000}$ & $65 \mathrm{MPH}$ & $30^{\prime}$ & 8.41 & 8.17 & 9.25 & 7.87 & $\underline{7.69}$ & 8.89 & $-6.5 \%$ & $-5.8 \%$ & $-3.9 \%$ \\
\hline $65 \mathrm{mph}, 40 \mathrm{ft}$ & $\overline{\text { Baseline } 2}$ & 65,000 & $\overline{65 \mathrm{MPH}}$ & $\overline{40^{\prime}}$ & 8.61 & $\overline{8.08}$ & $\overline{9.27}$ & $\overline{8.02}$ & $\overline{7.68}$ & 8.87 & $-6.9 \%$ & $-5.0 \%$ & $-4.3 \%$ \\
\hline $65 \mathrm{mph}, 40 \mathrm{ft}$ & Baseline 2 & 65,000 & $65 \mathrm{MPH}$ & $40^{\prime}$ & 8.72 & 8.20 & 9.50 & 8.10 & 7.78 & 9.10 & $-7.0 \%$ & $-5.2 \%$ & $-4.2 \%$ \\
\hline $65 \mathrm{mph}, 40 \mathrm{ft}$ & Baseline 2 & 65,000 & $65 \mathrm{MPH}$ & $40^{\prime}$ & 8.73 & 8.22 & 9.48 & 8.11 & 7.78 & 9.07 & $-7.1 \%$ & $-5.4 \%$ & $-4.3 \%$ \\
\hline $65 \mathrm{mph}, 40 \mathrm{ft}$ Average & Baseline 2 & $\underline{65,000}$ & $65 \mathrm{MPH}$ & $\underline{40^{\prime}}$ & 8.69 & 8.17 & 9.42 & 8.08 & 7.74 & 9.01 & $-7.0 \%$ & $-5.2 \%$ & $-4.3 \%$ \\
\hline $65 \mathrm{mph}, 50 \mathrm{ft}$ & Baseline 1 & 65,000 & $65 \mathrm{MPH}$ & $50^{\prime}$ & 9.28 & 8.68 & 10.14 & 8.69 & 8.28 & 9.81 & $-6.3 \%$ & $-4.6 \%$ & $-3.3 \%$ \\
\hline $65 \mathrm{mph}, 50 \mathrm{ft}$ & Baseline 1 & 65,000 & $65 \mathrm{MPH}$ & $50^{\prime}$ & 8.93 & 8.34 & 9.53 & 8.38 & 7.96 & 9.20 & $-6.2 \%$ & $-4.6 \%$ & $-3.5 \%$ \\
\hline $65 \mathrm{mph}, 50 \mathrm{ft}$ & Baseline 1 & 65,000 & $65 \mathrm{MPH}$ & $50^{\prime}$ & 8.98 & 8.40 & 9.60 & 8.44 & 8.03 & 9.31 & $-6.0 \%$ & $-4.4 \%$ & $-3.0 \%$ \\
\hline $65 \mathrm{mph}, 50 \mathrm{ft}$ Average & Baseline 1 & $\underline{65,000}$ & $65 \mathrm{MPH}$ & $\underline{50^{\prime}}$ & 9.06 & 8.47 & 9.76 & 8.50 & 8.09 & 9.44 & $-6.2 \%$ & $-4.6 \%$ & $-3.3 \%$ \\
\hline $65 \mathrm{mph}, 75 \mathrm{ft}$ & $\overline{\text { Baseline } 1}$ & 65,000 & $65 \mathrm{MPH}$ & $75^{\prime}$ & 9.05 & 8.29 & 9.60 & 8.50 & 7.91 & 9.32 & $-6.1 \%$ & $-4.7 \%$ & $-2.9 \%$ \\
\hline $65 \mathrm{mph}, 75 \mathrm{ft}$ & Baseline 1 & 65,000 & $65 \mathrm{MPH}$ & $75^{\prime}$ & 9.16 & 8.43 & 9.82 & 8.61 & 8.03 & 9.55 & $-6.0 \%$ & $-4.8 \%$ & $-2.8 \%$ \\
\hline $65 \mathrm{mph}, 75 \mathrm{ft}$ & Baseline 1 & 65,000 & $65 \mathrm{MPH}$ & $75^{\prime}$ & 9.01 & 8.29 & 9.45 & 8.44 & 7.89 & 9.10 & $-6.2 \%$ & $-4.8 \%$ & $-3.7 \%$ \\
\hline $65 \mathrm{mph}, 75 \mathrm{ft}$ Average & Baseline 1 & 65,000 & $65 \mathrm{MPH}$ & $\underline{75}$ & 9.07 & 8.34 & 9.62 & 8.52 & 7.94 & 9.32 & $-6.1 \%$ & $-4.7 \%$ & $-3.1 \%$ \\
\hline $70 \mathrm{mph}, 30 \mathrm{ft}$ & & 65,000 & $70 \mathrm{MPH}$ & $30^{\prime}$ & 9.31 & 9.38 & 10.61 & 8.87 & 9.05 & 10.39 & $-4.7 \%$ & $-3.6 \%$ & $-2.1 \%$ \\
\hline $70 \mathrm{mph}, 30 \mathrm{ft}$ & & 65,000 & $70 \mathrm{MPH}$ & $30^{\prime}$ & 9.43 & 9.48 & 10.85 & 8.99 & 9.16 & 10.61 & $-4.7 \%$ & $-3.4 \%$ & $-2.2 \%$ \\
\hline $70 \mathrm{mph}, 30 \mathrm{ft}$ Average & & $\underline{65,000}$ & $70 \mathrm{MPH}$ & $\underline{30}$ & 9.37 & 9.43 & $\underline{\underline{10.73}}$ & 8.93 & 9.10 & $\underline{10.50}$ & $-4.7 \%$ & $-3.5 \%$ & $-2.2 \%$ \\
\hline $70 \mathrm{mph}, 50 \mathrm{ft}$ & & 65,000 & $70 \mathrm{MPH}$ & $50^{\prime}$ & 9.64 & 9.09 & 10.80 & 9.14 & 8.71 & & $-5.1 \%$ & $-4.2 \%$ & \\
\hline $70 \mathrm{mph}, 50 \mathrm{ft}$ & & 65,000 & $70 \mathrm{MPH}$ & $50^{\prime}$ & 9.45 & 8.96 & 10.58 & 8.92 & 8.58 & 10.30 & $-5.6 \%$ & $-4.2 \%$ & $-2.6 \%$ \\
\hline $70 \mathrm{mph}, 50 \mathrm{ft}$ Average & & 65,000 & $70 \mathrm{MPH}$ & $\underline{50^{\prime}}$ & 9.54 & 9.02 & 10.69 & 9.03 & 8.65 & 10.30 & $-5.3 \%$ & $-4.2 \%$ & $-3.6 \%$ \\
\hline & & & & & & & & & & & & & \\
\hline $55 \mathrm{mph}, 30 \mathrm{ft}$ & & 65,000 & $55 \mathrm{MPH}$ & $30^{\prime}$ & 7.27 & 7.12 & 7.83 & 6.80 & 6.67 & 7.41 & $-6.4 \%$ & $-6.4 \%$ & $-5.4 \%$ \\
\hline $55 \mathrm{mph}, 30 \mathrm{ft}$ & & 65,000 & $55 \mathrm{MPH}$ & $30^{\prime}$ & 7.15 & 6.96 & 7.68 & 6.66 & & 7.24 & $-6.9 \%$ & & $-5.7 \%$ \\
\hline $55 \mathrm{mph}, 30 \mathrm{ft}$ Average & & 65,000 & $55 \mathrm{MPH}$ & $\underline{30^{\prime}}$ & 7.21 & 7.04 & 7.76 & 6.73 & 6.67 & 7.33 & $-6.6 \%$ & $-5.3 \%$ & $-5.5 \%$ \\
\hline $55 \mathrm{mph}, 50 \mathrm{ft}$ & & 65,000 & $55 \mathrm{MPH}$ & $50^{\prime}$ & 7.48 & 7.02 & 7.88 & 6.97 & 6.69 & 7.42 & $-6.9 \%$ & $-4.6 \%$ & $-5.9 \%$ \\
\hline $55 \mathrm{mph}, 50 \mathrm{ft}$ & & 65,000 & $55 \mathrm{MPH}$ & $50^{\prime}$ & 7.41 & 7.01 & 7.79 & 6.88 & & 7.34 & $-7.1 \%$ & & $-5.8 \%$ \\
\hline $55 \mathrm{mph}, 50 \mathrm{ft}$ Average & & $\underline{65,000}$ & $55 \mathrm{MPH}$ & $\underline{50^{\prime}}$ & 7.44 & 7.01 & 7.84 & 6.93 & 6.69 & 7.38 & $-7.0 \%$ & $-4.6 \%$ & $-5.8 \%$ \\
\hline & & & & & & & & & & & & & \\
\hline \begin{tabular}{|l|} 
Variable Speed Test \\
Variable Speed Test \\
\end{tabular} & & 65,000 & \begin{tabular}{|l|} 
VAR MPH \\
VAR MPH \\
\end{tabular} & $\begin{array}{l}50^{\prime} \\
50^{\prime}\end{array}$ & $\begin{array}{l}8.92 \\
8.87\end{array}$ & & $\begin{array}{l}9.95 \\
10.29 \\
\end{array}$ & & 8.33 & $\begin{array}{c}9.81 \\
10.23 \\
\end{array}$ & $\begin{array}{l}-4.8 \% \\
-4.6 \% \\
\end{array}$ & $\begin{array}{l}-3.4 \% \\
-3.3 \% \\
\end{array}$ & $\begin{array}{l}-1.4 \% \\
-0.6 \% \\
\end{array}$ \\
\hline Variable Speed Test Average & & $\underline{65,000}$ & VARMPH & $\underline{50^{\prime}}$ & $\underline{8.89}$ & 8.64 & $\underline{10.12}$ & $\underline{8.48}$ & $\underline{8.35}$ & $\underline{10.02}$ & $-4.7 \%$ & $-3.4 \%$ & $-1.0 \%$ \\
\hline & & & & & & & & & & & & & \\
\hline 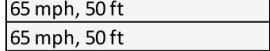 & & $\begin{array}{l}80,000 \\
80,000\end{array}$ & $\begin{array}{l}65 \mathrm{MPH} \\
65 \mathrm{MPH} \\
\end{array}$ & $\begin{array}{l}50^{\prime} \\
50^{\prime}\end{array}$ & & & & & & & $\begin{array}{l}-4.9 \% \\
-5.8 \%\end{array}$ & & $\begin{array}{l}-1.2 \% \\
-1.8 \% \\
\end{array}$ \\
\hline $65 \mathrm{mph}, 50 \mathrm{ft}$ Average & & 80,000 & $65 \mathrm{MPH}$ & $\underline{50^{\prime}}$ & 9.20 & 9.04 & 10.24 & 8.71 & 8.42 & 10.08 & $-5.4 \%$ & $-6.8 \%$ & $-1.5 \%$ \\
\hline $65 \mathrm{mph}$ Baseline 1 & & 65,000 & $65 \mathrm{MPH}$ & -- & 9.48 & 9.49 & 10.00 & 8.88 & & 9.66 & $-6.3 \%$ & & $-3.4 \%$ \\
\hline $65 \mathrm{mph}$ Baseline 1 & & 65,000 & $65 \mathrm{MPH}$ & -- & 9.03 & 9.02 & 9.39 & 8.46 & 8.58 & 9.03 & $-6.3 \%$ & $-4.9 \%$ & $-3.8 \%$ \\
\hline $65 \mathrm{mph}$ Baseline 1 & & 65,000 & $65 \mathrm{MPH}$ & -- & 9.01 & 8.94 & 9.33 & 8.48 & 8.51 & 8.98 & $-5.9 \%$ & $-4.8 \%$ & $-3.7 \%$ \\
\hline $65 \mathrm{mph}$ Baseline 1 Average & & 65,000 & $65 \mathrm{MPH}$ & 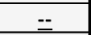 & 9.18 & 9.15 & 9.57 & 8.61 & 8.54 & 9.22 & $-6.2 \%$ & $-6.6 \%$ & $-3.6 \%$ \\
\hline $65 \mathrm{mph}$ Baseline 2 & & 65,000 & $65 \mathrm{MPH}$ & -- & 8.83 & 8.89 & & 8.22 & 8.41 & 8.90 & $-6.8 \%$ & $-5.4 \%$ & $-4.3 \%$ \\
\hline $65 \mathrm{mph}$ Baseline 2 & & 65,000 & $65 \mathrm{MPH}$ & -- & 8.84 & 8.90 & 9.31 & 8.24 & 8.45 & 8.94 & $-6.8 \%$ & $-5.1 \%$ & $-4.0 \%$ \\
\hline $65 \mathrm{mph}$ Baseline 2 & & 65,000 & $65 \mathrm{MPH}$ & -- & & & & & 8.47 & 9.01 & $-6.7 \%$ & $-5.0 \%$ & $-3.7 \%$ \\
\hline $65 \mathrm{mph}$ Baseline 2 Average & & 65,000 & $65 \mathrm{MPH}$ & $=$ & 8.84 & 8.90 & 9.33 & 8.24 & 8.44 & 8.95 & $-6.8 \%$ & $-5.2 \%$ & $-4.0 \%$ \\
\hline $70 \mathrm{mph}$ Baseline & & 65,000 & $70 \mathrm{MPH}$ & -- & & & 10.71 & & 9.43 & 10.45 & $-5.2 \%$ & $-4.3 \%$ & $-2.5 \%$ \\
\hline $70 \mathrm{mph}$ Baseline & & 65,000 & $70 \mathrm{MPH}$ & -- & 9.70 & 9.79 & 10.62 & & 9.36 & 10.33 & & $-4.4 \%$ & $-2.7 \%$ \\
\hline $70 \mathrm{mph}$ Baseline Average & & $\underline{65,000}$ & $70 \mathrm{MPH}$ & $=$ & 9.74 & 9.83 & $\underline{10.66}$ & 9.27 & 9.40 & 10.39 & $-4.8 \%$ & $-4.4 \%$ & $-2.6 \%$ \\
\hline $55 \mathrm{mph}$ & & & & -- & & & & & & & & & \\
\hline $55 \mathrm{mph}$ Baseline & & 65,000 & $55 \mathrm{MPH}$ & -- & 7.61 & 7.75 & & 7.11 & 7.36 & 7.39 & $-6.6 \%$ & $-4.9 \%$ & $-5.6 \%$ \\
\hline $55 \mathrm{mph}$ Baseline Average & & 65,000 & $55 \mathrm{MPH}$ & $=$ & 7.51 & 7.67 & 7.73 & 7.02 & 7.29 & 7.30 & $-6.6 \%$ & $-4.9 \%$ & $-5.6 \%$ \\
\hline & & & & & & & & & & & & & \\
\hline Variable Speed Baseline & & 65,000 & VARMPH & -- & 9.23 & 9.09 & 10.25 & 8.76 & 8.66 & 9.73 & $-5.1 \%$ & $-4.8 \%$ & $-5.1 \%$ \\
\hline Variable Speed Baseline & & 65,000 & VARMPH & -- & 9.09 & 8.98 & 10.03 & & 8.60 & 9.59 & & $-4.3 \%$ & $-4.4 \%$ \\
\hline Variable Baseline Average & & $\underline{65,000}$ & VAR MPH & $=$ & 9.16 & 9.04 & $\underline{10.14}$ & 8.76 & 8.63 & 9.66 & $-4.4 \%$ & $-4.6 \%$ & $-4.7 \%$ \\
\hline & & & & & & & & & & & & & \\
\hline $65 \mathrm{mph}$ Baseline & & 80,000 & $65 \mathrm{MPH}$ & -- & 9.23 & 9.65 & 10.25 & 8.76 & 9.27 & 10.11 & $-5.2 \%$ & $-3.9 \%$ & $-1.4 \%$ \\
\hline $65 \mathrm{mph}$ Baseline & & 80,000 & $65 \mathrm{MPH}$ & -- & 9.11 & 9.53 & 10.03 & 8.63 & 9.16 & 9.89 & $-5.3 \%$ & $-3.9 \%$ & $-1.4 \%$ \\
\hline $65 \mathrm{mph}$ Baseline Average & & 80,000 & $65 \mathrm{MPH}$ & $-z$ & 9.17 & 9.59 & 10.14 & 8.69 & 9.22 & 10.00 & $-5.2 \%$ & $-3.9 \%$ & $-1.4 \%$ \\
\hline
\end{tabular}

This is a work of a Government and is not subject to copyright protection. Foreign copyrights may apply. The Government under which this paper was written assumes no liability or responsibility for the contents of this paper or the use of this paper, nor is it endorsing any manufacturers, products, or services cited herein and any trade name that may appear in the paper has been included only because it is essential to the contents of the paper.

Positions and opinions advanced in this paper are those of the author(s) and not necessarily those of SAE International. The author is solely responsible for the content of the paper. 